\title{
Agama dan Modernitas dalam Praktik Ritual Mandi Safar di Kayong Utara
}

\author{
Wahab $^{\mathrm{a}, 1, *}$, Hariansyah ${ }^{\mathrm{b}, \mathrm{c}, 2}$, Dewi Nurhayati ${ }^{\mathrm{b}, 3}$ \\ ${ }^{a b c}$ Institut Agama Islam Negeri Pontianak (IAIN Pontianak), Jl Letjen SoepraptoNo 19, Pontianak 78122, Indonesia \\ ${ }^{1}$ abdulwahabassambasi@gmail.com*; ${ }^{2}$ shah4shah19@gmail.com; ${ }^{3}$ dewinurhayaty21633@gmail.com)
}

ARTICLE INFO

Article history:

Received : 2019-11-26

Revised : 2019-12-26

Accepted : 2019-12-26

Keywords:

Religion,

Belief,

Modernity,

Safar Month

North Kayong

Kata Kunci :

Agama,

Kepercayaan,

Modernitas,

Bulan Safar,

Kayong Utara

\section{ABSTRACT}

The Sungai Jambu Malay society believes that the Safar Month brings curses and illness. Avoiding this, the local community does the Safar bath ritual by reading selected shurah in the Qur'an, performing ablution, praying safely, praying rejecting curses, blessings to the Prophet, Zikir, swearing the utterance that there is no god but Allah, helping each other, friendship, eating together, praying the intention to do Safar bath with the aim to obtain safety and avoid curses in the month of Safar. This study uses a qualitative approach with ethnographic methods. The subject of the study is religious leaders and customary leaders. The techniques used in the study are non-participant observation, phone interviews and direct interviews. The study revealed that the Sungai Jambu Malay society praying for the safety, praying for longevity and rejecting disasters are a form of confidence in order that they saved from disasters and illness in the Safar month. Besides reading the surahs of al-Fatihah, al-Ikhlas, an-Naas and al-Falak to get a reward from Allah Subhanahu wa ta'ala, doing ritual bath during the safar month for the Sungai Jambu Malay society is the purification from disasters and disease. In addition, bathing also removes odors, dust, and moisturizes the skin. However, the belief of the Sungai Jambu Malay society towards the Safar month, which brought curses and illness, there is a gap and contrary to the valid Hadith regarding the safar month.

\section{ABSTRAK}

Masyarakat Melayu Sungai Jambu mempercayai bahwa bulan safar bulan yang mendatangkan bala' dan penyakit, untuk menghindari hal tersebut masyarakat setempat melaksanakan Ritual Mandi Safar dengan membaca surat-surat pilihan dalam al-Qur'an, berwudhu, do'a selamat, do'a tolak bala, shalawat, zikir, mengucapkan kalimat Tidak Ada Tuhan Selain Allah, tolong-menolong, silaturrahim, makan bersama-sama, do'a niat Mandi Safar dengan tujuan untuk memperoleh keselamatan dan menghindari kesialan di bulan safar. Penelitian ini menggunakan pendekatan kualitatif dengan metode etnografi, subjek penelitian ini adalah tokoh agama dan ketua adat, teknik yang digunakan untuk memperoleh informasi atau data adalah observasi non partisipan, wawancara melalui via telepon dan wawancara langsung. Dari hasil penelitian bahwa bagi masyarakat Melayu Sungai Jambu membaca do'a selamat, do'a memohon panjang umur dan do'a tolak bala' adalah bentuk keyakinan agar selamat dari bala' dan penyakit pada bulan safar. Selain itu membaca surah-surah al-Fatihah, al-Ikhlas, an-Naas dan al-Falak mendapatkan pahala dari Allah Subhanahu wa ta'ala. Mandi pada bulan safar bagi masyarakat Melayu Sungai Jambu adalah 
bersucinya dari bala' dan penyakit. Selain itu, mandi juga menghilangkan bau, debu, dan melembabkan kulit. Namun, kepercayaan masyarakat Melayu Sungai Jambu terhadap bulan safar bulan yang mendatangkan bala' dan penyakit terdapat kesenjangan dan bertolak belakang dengan hadis-hadis shahih mengenai bulan safar.

\section{Pendahuluan}

Mengenai kebudayaan tidak terlepas dari kehidupan manusia. Oleh karenanya, kebudayaan sebagai identitas dan ciri khas yang berbeda-beda dari setiap golongan masyarakat. Berdasarkan hal tersebut, kebudayaan adalah keseluruhan dari kehidupan manusia yang terpola dan didapatkan dengan belajar atau yang diwariskan kepada generasi berikutnya, baik yang masih dalam pikiran, perasaan dan hati pemiliknya, maupun yang sudah lahir dalam bentuk tindakan dan benda. (9)

Oleh karena itu, kata kebudayaan berasal dari kata budh dalam bahasa Sanskerta yang berarti akal, kemudian menjadi kata budhi (tunggal) atau budhayat (majemuk), sehingga kebudayaan diartikan sebagai hasil pemikiran atau akal manusia. (55) Lebih lanjut, dalam rangka bertahan atau survive, maka manusia harus mampu memenuhi apa yang menjadi kebutuhannya sehingga manusia melakukan berbagai cara agar tetap mampu beradaptasi dengan perubahan sosial yang terjadi. Apa yang dilakukan oleh manusia tersebut dapat disebut sebagai proses kebudayaan. (49)

Oleh karena itu, kebudayaan adalah "culture is the acquired knowledge that people use to interperet experience and to generate social behavior...we speak of them as cultural knowledge, cultural behavior and cultural artefacts" (Kebudayaan adalah pengetahuan yang diperoleh yang digunakan penduduk untuk menginterpretasi pengalaman dan melahirkan tingkah laku sosial. Dikatakan bahwa semua itu sebagai kebudayaan pengetahuan, kebudayaan tingkah laku dan kebudayaan kebendaan).(9)

Lebih lanjut kebudayaan adalah segala hal yang dimiliki oleh manusia, yang hanya diperolehnya dengan belajar dan menggunakan akalnya.(22) Di dalam buku "Kebudayaan Mentalitas dan Pembangunan" bahwa banyak orang terutama para ahli ilmu sosial, mengartikan konsep kebudayaan itu dalam arti yang amat luas yaitu seluruh total dari pikiran, karya, dan hasil karya manusia yang tidak berakar kepada nalurinya, dan yang karena itu hanya bisa dicetuskan oleh manusia sesudah suatu proses belajar.

Oleh karena itu, Koentjaraningrat membagi unsur-unsur kebudayaan yang universal, unsur tersebut adalah sistem religi dan upacara keagamaan, sistem dan organisasi kemasyarakatan, sistem pengetahuan, bahasa, kesenian, sistem mata pencaharian hidup, sistem teknologi dan peralatan.(22) Pendapat tersebut sedikit berbeda dengan bahwa unsur kebudayaan yang cenderung bertahan di antaranya adalah unsur kebudayaan yang mempunyai fungsi yang terjaring luas dalam masyarakat, unsur kebudayaan yang dipelajari pada tingkat awal dalam proses sosialisasi, unsur kebudayaan yang termasuk agama atau religi, unsur kebudayaan yang menyangkut ideologi, dan unsur kebudayaan yang termasuk adat istiadat.

Sebagai masyarakat yang memiliki keragaman kebudayaan atau yang dikenal dengan multikulturalisme tentu memiliki nilai-nilai budaya lokal atau yang disebut dengan kearifan lokal yang dituangkan dalam berbagai tradisi. (63) Lebih lanjut dikemukakan oleh (40) kearifan lokal juga perlu digali dan dipromosikan sehingga dapat menjadi pembelajaran bagi komunitas lain. Belajar dari kearifan lokal suatu masyarakat berguna bagi masyarakat lain sebab nilainilai kearifan lokal sudah pasti merupakan sesuatu yang sudah teruji oleh ruang dan waktu. Oleh karena itu tidak perlu diragukan lagi bahwa kearifan lokal dapat menjadi model dalam kehidupan masyarakat. (62)

Berbicara nilai-nilai kearifan lokal bahwa sistem, nilai, norma, dan tradisi yang tumbuh dan berkembang menjadi kearifan lokal merupakan suatu potensi nilai-nilai dan norma yang ada dalam dalam masyarakat yang dapat digunakan sebagai salah satu tools (alat) dalam proses penguatan relasi sosial, baik dalam komunitas maupun antara komunitas. (45)

Pendapat yang hampir sama yang membahas nilai-nilai kearifan lokal juga sekurang-kurangnya ada enam nilai yang amat menentukan wawasan etika dan 
kepribadian manusia sebagai individu maupun sebagai masyarakat, yaitu:

\section{Nilai teori}

Ketika manusia menentukan dengan objektif identitas benda-benda atau kejadian-kejadian, maka dalam prosesnya hingga menjadi pengetahuan, manusia mengenal adanya teori yang menjadi konsep dalam proses penilaian atas alam sekitar.

2. Nilai ekonomi

Ketika manusia bermaksud menggunakan benda-benda atau kejadiankejadian, maka ada proses penilaian ekonomi atau kegunaan, yakni dengan logika efisiensi untuk memperbesar kesenangan hidup. Kombinasi antara nilai teori dan nilai ekonomi yang senantiasa maju disebut aspek progresif dari kebudayaan.

3. Nilai agama

Ketika manusia menilai suatu rahasia yang menakjubkan dan kebesaran yang menggetarkan di mana di dalamnya ada konsep kekudusan dan ketakziman kepada yang Mahagaib, maka manusia mengenal nilai agama.

4. Nilai seni

Jika yang dialami itu keindahan di mana ada konsep estetika dalam menilai benda atau kejadian-kejadian, maka manusia mengenal nilai seni. Kombinasi dari nilai agama dan seni yang sama-sama menekankan intuisi, perasaan, dan fantasi disebut aspek ekspresif dari kebudayaan.

5. Nilai kuasa

Ketika manusia merasa puas jika orang lain mengikuti pikirannya, normanormanya, dan kemauannya, maka ketika itu manusia mengenal nilai kuasa.

6. Nilai solidaritas

Tetapi ketika hubungan itu menjelma menjadi cinta, persahabatan, dan simpati sesama manusia, menghargai orang lain, dan merasakan kepuasan ketika membantu mereka maka manusia mengenal nilai solidaritas. (49)

Oleh karena itu, dalam sistem nilai budaya orang Indonesia nilai itu mengandung empat konsep, yakni: 1) manusia itu tidak hidup sendiri di dunia ini, tetapi dikelilingi oleh komunitasnya, masyarakatnya, dan alam semesta sekitarnya, 2) dengan demikian dalam segala aspek kehidupannya manusia pada hakikatnya tergantung pada sesamanya,
3) karena itu ia harus selalu berusaha untuk sedapat mungkin memelihara hubungan baik dengan sesamanya, terdorong oleh jiwa sama-rata-sama-rasa, dan 4) selalu berusaha untuk sedapat mungkin bersifat konform, berbuat sama dan bersama dengan sesamanya dalam komunitas, terdorong oleh jiwa samatinggi-sama-rendah. (22)

Dari berbagai pernyataan di atas mengenai budaya lokal itu sendiri terdapat pada Ritual Mandi Safar oleh masyarakat Melayu Sungai Jambu di Kayong Utara. Tradisi tersebut telah turun-temurun dilaksanakan oleh Masyarakat setempat karena dipercaya sebagai upaya menolak bala' di bulan Safar. Bulan Safar dipercaya sebagai bulan yang banyak mengandung bala' atau na'as, sehingga Mandi Safar ditujukan untuk membersihkan diri agar terhindar dari bala ataupun na'as. Berawal dari kepercayaan terhadap bulan safar bulan yang mendatangkan bala', maka pada bulan tersebut harus melaksanakan tradisi yang bernama Mandi Safar. Sementara itu, berdasarkan informasi dari masyarakat setempat bahwa Ritual Mandi Safar masih ada pro dan kontra. Berikut peneliti paparkan di bawah ini:

Oleh karena itu, Datuk Abdul Mu'in selaku ketua adat dan tokoh agama Dusun Sungai Jambu Kabupaten Kayong Utara (41)"According to Datuk Mu'in as adat leader and religious leader of Sungai Jambu subvillage, North Kayong Regency, the origin of the emergence of the Safar Bath Tradition originated from the people's belief in the disaster or the disaster in the month of Safar (collision or accident).

In addition, the Tradition of the Safar Bath was carried out to follow the instructions of the Prophet Muhammad while spreading Islamic da'wah, his preaching was blocked by unbelievers who had the intention to kill him. At the time of the assassination plan Prophet Muhammad sallalla Alaihi Wa Sallam hid in Gua Hira in the month of Safar and read seven verses of the Koran or socalled Salamun Tujuh (seven welfare) and after reading the verse Prophet Muhammad sallallaahu 'Alaihi Wa Sallam disappeared or with the word other infidels do not see the Prophet Muhammad sallallaahu 'Alaihi Wa Sallam in Gua Hira" (Asal mula munculnya tradisi mandi safar itu berawal dari kepercayaan masyarakat terhadap bala atau 
musibah pada bulan Safar (tabrakan atau kecelakaan dan penyakit). (40)

Selain itu, Tradisi Mandi Safar dilaksanakan untuk mengikuti petunjuk Nabi Muhammad Shallallahu 'Alaihi Wa Sallam saat menyebarkan dakwah Islam, namun dakwahnya tersebut dihalang oleh orangorang kafir yang mempunyai niat untuk membunuhnya. Namun, di saat rencana pembunuhan itu Nabi Muhammad Shallallahu 'Alaihi Wa Sallam bersembunyi di Gua Hira pada bulan safar dan membaca tujuh ayat Al-Qur'an atau yang disebut dengan Salamun Tujuh (tujuh kesejahteraan) dan setelah membaca ayat tersebut Nabi Muhammad Shallallahu 'Alaihi Wa Sallam hilang atau dengan kata lain orang-orang kafir tidak melihat Nabi Muhammad Shallallahu 'Alaihi Wa Sallam di Gua Hira).

Lebih lanjut, Datuk Agok selaku tokoh agama Masyarakat Melayu Dusun Sungai Jambu mengatakan Tradisi Mandi Safar dilaksanakan pada bulan safar, sehingga bulan safar dianggap bulan yang na'as. Demikian menurut Mariana, a 34-year old (41) "resident of Sungai Jambu Sub village stated that the Andung-andung leaves when written in the seven salamun verses were not easily destroyed, besides the width and hardness of the leaves. The meaning of the ktupat is a welcome to celebrate the salvation of the reinforcements in the month of Safar" (Lebih lanjut menurut Mariana salah seorang warga Dusun Sungai Jambu yang berusia 34 tahun menyatakan makna dari daun andungandung ketika dituliskan ayat salamun tujuh tidak mudah hancur, selain itu juga lebar dan keras daunnya. Makna dari ketupat lepas sebagai sambutan untuk merayakan keselamatan dari bala pada bulan safar).

Berdasarkan pandangan masyarakat tersebut, Datuk Jainul selaku tokoh agama Masyarakat Melayu Sungai Jambu berbeda pendapat mengenai bulan safar. Menurutnya tradisi tersebut tidak dilaksanakan juga tidak mendatangkan na'as atau bala'. Pendapat yang sama dikemukakan Datuk Agok bahwa jika tradisi tersebut tidak dilaksanakan juga tidak mendatangkan na' as atau bala'. (40)

Mengenai pendapat masyarakat tersebut yang mengatakan bulan safar bukan bulan na'as atau bala' (23) Bahwa Mandi Safar seperti halnya tradisi-tradisi lain yang berkembang di masyarakat, meskipun terkesan merupakan tradisi yang bernuansa agama, namun pada dasarnya tradisi tersebut bukanlah bagian dari agama.

Oleh karena itu, dalam upacara ritual Mandi Safar yang perlu dikedepankan adalah aspek "tradisi dan budayanya" bukan aspek ritual keagamaannya. Sebab jika Mandi Safar dianggap sebagai ritual keagamaan yang ditandai misalnya dengan niat yang percaya pada yang gaib terhadap Mandi Safar, menuliskan ayat-ayat tertentu pada daun, maka hal tersebut dikhawatirkan akan melahirkan pemahaman di kalangan masyarakat bahwa Mandi Safar atau ayat tersebut yang menyembuhkan, menyelamatkan, dan menghindarkan orang dari segala macam bala dan bencana.

Hal tersebut berdasarkan hasil dari pemahaman masing-masing oleh masyarakat setempat. Akan tetapi, jika masyarakat mempercayai ayat-ayat Al-Qur'an sebagai penyembuh dari penyakit dan mencegah terjadinya na'as atau bala, maka hal tersebut sebagai bentuk memohon perlindungan kepada Allah Subhanahu wa ta'ala. (23)

Lebih lanjut Menjelaskan bahwa Tradisi Mandi Safar adalah upaya do'a untuk keselamatan yang diwujudkan dalam Praktik tradisional, seperti minum dan mandi dengan air yang mengandung do'a. Do'a Mandi Safar yang berisikan tujuh ayat al-Qur'an yang kesemuanya berawal "salamun", bertujuan untuk memohon keselamatan. Do'a Mandi Safar sebagian ada yang ditulis sebagian ada yang langsung dibaca, bahkan menghafalnya. Membaca ayat al-Qur'an adalah bertujuan untuk memohon syafa'at, memohon dengan penuh harapan dan optimisme. Dalam bahasa agama dikenal dengan istilah "tafa'ul". Mandi dan minum dengan ayat hanyalah perantara, namun yang menyembuhkan adalah Allah Subhanahu wata'ala. (23)

Jadi, kepercayaan masyarakat Melayu Sungai Jambu di Kayong Utara mengenai bulan safar bulan yang mendatangkan bala' atau na'as bertolak belakang dengan hadis yang membahas bulan safar bukan bulan sial yakni peneliti mengutip hadist tersebut dalam Jurnal An-Nuha yang ditulis oleh (43) bahwa Rasulullah bersabda:

عن أبى هر ير ة ربضى اله عنه قال: قال رسول الله

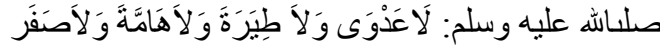
Tidak ada penyakit yang menular, tidak ada (keyakinan bahwa) tulang orang yang mati itu akan menjadi burung, dan tidak ada bulan safar (bulan sial).(HR. Al-Bukhari No. 
5437, HR. Muslim No. 2220, HR. Abu Daud No. 3911, dan HR. Ahmad II No. 327) (42)

Dari beberapa pendapat di atas, menyatakan bahwa bulan Safar bukan bulan sial karena pernyataan tersebut bersumber dari dalil naqli. Oleh karena itu, bulan safar bukan bulan yang mendatangkan penyakit dan bernasib sial. Dalil-dalil bulan safar sebagai fondasi keyakinan atau akidah masyarakat Melayu Sungai Jambu yang mana dalil tersebut sebagai pedoman untuk mengukuhkan akidah masyarakat yang sebelumnya mempercayai bahwa bulan safar bulan bala' atau na' as. Selain itu, masyarakat Melayu Sungai Jambu juga mempercayai bahwa ayat-ayat Al-Qur'an yang dituliskan ke daun andung-andung dan kemudian direndam ke air sebagai penolak bala' atau na'as.

Namun, dibalik akidah masyarakat terhadap Ritual Mandi Safar juga terdapat dampak positif yang mana peneliti melihat bahwa dalam rangkaian kegiatan tradisi tersebut terdapat unsur-unsur membaca do'a selamat, do'a tolak bala', akidah (tauhid), zikir, shalawat, membaca ayat-ayat AlQur'an, silaturrahim, sedekah, makan, minum, serta berbuat baik kepada sesama manusia dan melestarikan lingkungan.

Selain itu, Masyarakat Melayu Sungai Jambu ini memiliki keunikan khususnya pada Ritual Mandi Safar. Keunikan dari tradisi tersebut adalah apabila ibu hamil yang melahirkan pada bulan Safar dan kemudian ibu dan bayinya selamat maka bayi tersebut dibacakan serakal oleh tokoh agama dan ketua adat, setelah itu gunting rambut selama tiga tahun berturut-turut melakukan tumbang apam pada setiap bulan safar.

Tidak hanya itu, bagi masyarakat Melayu Sungai Jambu pantang larang juga ada pada bulan safar. Contoh pantang larang pada bulan safar adalah telur ayam yang sudah dierami induknya tidak menetas dan ketika melakukan perjalanan pada bulan safar akan mendapatkan musibah jika belum melakukan Mandi Safar. Selanjutnya, Ritual Mandi Safar dilaksanakan pada bulan safar dikarenakan mandi pada bulan tersebut terdapat kebersamaan artinya mandi secara bersama-sama di parit serta menjalin silaturrahim antar sesama.

Berdasarkan fenomena di atas, Ritual Mandi Safar selain menarik dari sisi keyakinan mengenai bulan safar bulan yang mendatangkan naas atau bala' sehingga melaksanakan ritual tersebut ternyata juga mempercayai pantang larang terhadap bulan safar yang sebelumnya telah peneliti paparkan di atas. Oleh karena itu, peneliti mengkaji lebih dalam mengenai apa sebenarnya urgensi dari Ritual Mandi Safar, dilihat dari "Agama dan Modernitas dalam Praktik Ritual Mandi Safar di Kayong Utara."

\section{Review Tinjauan Pustaka}

Pada pembahasan ini menyajikan teoriteori yang mendukung data yang telah diperoleh di lapangan.

1. Akidah dalam Praktik Ritual Mandi Safar pada Masyarakat Melayu Sungai Jambu di Kayong Utara.

Ritual Mandi Safar Oleh Masyarakat Melayu Sungai Jambu Kabupaten Kayong Utara bahwa pada pelaksanaan ritual tersebut masyarakat setempat percaya bahwa ayat-ayat Al-Qur'an yang dituliskan ke daun andung-andung dan direndamkan ke air parit sebagai penolak bala' atau na'as. Namun, kepercayaan masyarakat Melayu Dusun Sungai Jambu terhadap bulan safar adalah bulan yang mendatangkan na'as maka dari itu masyarakat setempat melaksanakan Ritual Mandi Safar dan jika tidak dilaksanakan maka akan mendatangkan na' as atau bala' sehingga pada bulan safar terhindar dari na' as atau bala' tersebut.

Selain itu, dalam pelaksanaan tradisi tersebut, sebagai bentuk memohon perlindungan kepada Allah Subhanahu wa ta'ala dan mempercayai bahwa Tiada Tuhan Selain Allah dengan membaca Laa Ilaaha Illallaah dan ayat-ayat Al-Qur'an. Tidak hanya itu, Masyarakat Melayu Sungai Jambu di Kayong Utara menyatakan Al-Qur'an sebagai petunjuk hidup.

Kaelany (2000:36) menjelaskan akidah adalah iman, keyakinan atau kepercayaan yang sungguh-sungguh dan murni yang tidak dicampuri oleh rasa ragu, sehingga kepercayaan dan keyakinan itu mengikat seseorang di dalam segala tindak tanduknya, sikap dan perilakunya seharihari. Pendapat yang demikian juga dikemukakan Ohan Sudjana (2000:1) akidah yakni pembenaran hati secara 
mutlak, sehingga benar-benar mencapai tingkat keyakinan (tidak ada keraguan dan kebimbangan, tidak menjadi insan roeb).

Oleh karena itu, (23) Dalam Islam, akidah merupakan ajaran pertama yang disyariatkan Allah melalui lisan Nabi Muhammad SAW dan mendasari ajaranajaran lain. Seluruh sendi ajaran Islam bertumpu pada akidah ini. Karenanya, akidah sering disebut sebagai asas atau rukun yang berarti pokok-pokok penyangga atau pondasi sebuah bangunan. Ibarat sebuah rumah, akidah merupakan pondasi yang akan menentukan kuat atau lemahnya rumah tersebut. Sebuah pondasi yang kokoh akan membuat rumah menjadi kuat dan tak tergoyahkan oleh gerakan bumi dan terpaan badai. Sebaliknya jika pondasi lemah, maka akan membuat rumah tersebut rentan roboh, walaupun hanya karena tiupan angin yang ringan atau goncangan sederhana.

Allah SWT memerintahkan para hamba untuk mentauhidkan diriNya (QS. Muhammad(41): 19) sebelum memberikan perintah yang lain. Itulah sebabnya awal dakwah Rasulullah SAW berusaha menempatkan akidah, yakni akidah tauhid "la ilaha illa Allah" dengan pemahaman yang benar dan murni. Akidah yang benar akan menghantarkan apa yang dilakukan manusia (walau sekecil apapun) menjadi tegak dan benar dan akan membawanya memperoleh rahmat Allah berupa surga-Nya.

Pemahaman secara benar terhadap makna akidah tauhid la ilaha illa Allah sebagai kunci dari seluruh ajaran Islam inilah yang masih sering dilalaikan oleh umat Islam. Akibatnya, pemelukan Islam mereka kurang atau bahkan tidak mantap sama sekali. Pada gilirannya kondisi ini menyebabkan umat Islam mudah terombang-ambing oleh badai dan godaan yang setiap saat siap mengoyak keimanan mereka. (21)

Akidah adalah suatu pokok atau dasar keyakinan yang harus dipegang oleh orang yang mempercayainya. Maka yang dimaksud dengan akidah Islam adalah pokok-pokok kepercayaan yang harus diyakini kebenarannya oleh setiap muslim berdasarkan dalil naqli dan aqli (nash dan akal).
Sedangkan dasar dari akidah Islam adalah Al-Qur'an dan Sunnah Rasul. Di dalam Al-Qur'an banyak disebutkan pokok-pokok akidah, yakni keimanan, maka akidah disini identik dengan keimanan. Ayat Al-Qur'an yang memuat kandungan akidah Islam, antara lain:

Artinya:"Rasul telah beriman kepada Al

Quran yang diturunkan kepadanya dari Tuhannya, demikian pula orang-orang yang beriman. semuanya beriman kepada Allah, malaikat-malaikatNya, kitab-kitab-Nya dan rasulrasul-Nya. (mereka mengatakan):

"Kami tidak membeda-bedakan antara seseorang pun (dengan yang lain) dari rasul-rasul-Nya", dan mereka mengatakan: "Kami dengar dan Kami taat." (mereka berdoa): "Ampunilah Kami Ya Tuhan Kami dan kepada Engkaulah tempat kembali."(QS. Al-Baqarah:258)

Dalam sebuah hadis riwayat Imam Muslim disebutkan:

"Hendaklah engkau beriman kepada Allah, para malaikat-Nya, kitab-kitabNya, para Rasul-rasul-Nya, hari akhir, dan hendaklah beriman kepada qadar ketentuan baik dan buruk. "(Al-Hadis).

Tujuan akidah Islam bagi setiap muslim adalah:

a. Memupuk dan mengembangkan dasar ketuhanan yang ada sejak lahir

b. Memelihara manusia dari kemusyrikan

c. Menghindarkan diri dari pengaruh akal yang menyesatkan

Manusia diberi kelebihan Allah berupa akal pikiran. Pendapat-pendapat atau paham-paham semata-mata didasarkan atas akal manusia, kadangkadang menyesatkan manusia itu sendiri. Oleh karena itu, pikiran manusia perlu dibimbing oleh akidah Islam agar terhindar dari kehidupan yang sesat. (66) Lebih lanjut, menyatakan Keimanan bukan sekedar percaya, melainkan membuahkan amal saleh, perbuatan yang diridhoi Allah. (37)

Lebih lanjut (11) Alquran merupakan kitab suci umat Islam yang diturunkan Allah kepada rasulnya yang terakhir yaitu nabi Muhammad SAW. Alquran sebagai kitab terakhir dimaksudkan untuk menjadi 
petunjuk bagi seluruh umat manusia (hudan linnas) sampai akhir zaman. Bukan cuma diperuntukkan bagi anggota masyarakat Arab tempat dimana kitab ini diturunkan akan tetapi untuk seluruh umat manusia. Di dalamnya terkandung nilainilai yang luhur yang mencakup seluruh aspek kehidupan manusia dalam berhubungan dengan Tuhan maupun hubungan manusia dengan sesama manusia lainnya dan hubungan manusia dengan alam sekitarnya. (12)

Oleh karena itu, "maka siapa yang hendak mengetahui sesuatu yang berada di luar jangkauan pengetahuannya dan tidak puas hanya dengan menyerahkan pemahamannya, maka hal itu akan menghalanginya dari tauhid yang ikhlas, pengetahuan yang jernih dan keimanan yang benar. Dia akan ragu-ragu, bimbang, dan gelisah antara mengimani dan membenarkan dengan mengingkari dan mendustakan. (39)

Lebih lanjut, menyatakan Aqidah secara istilah berarti sejumlah kebenaran yang dapat diterima secara umum oleh manusia berdasarkan fitrah, akal, dan wahyu, kemudian dipatrikan dalam hati, diyakini keshahihannya (kebenarannya) dan ditolak kebenaran selainnya. (59)

Lebih lanjut, ruang lingkup rukun iman atau akidah ada enam, yaitu:

1. Beriman kepada Allah

2. Beriman kepada malaikat-malaikat Allah

3. Beriman kepada kitab-kitab Allah

4. Beriman kepada rasul-rasul Allah

5. Beriman kepada hari akhir

6. Beriman kepada takdir Allah, takdir baik maupun buruk.

Dari ruang lingkup rukun iman di atas, penelitian ini terdapat relasi antara beriman kepada takdir Allah, takdir baik maupun buruk. Yang dimaksud dengan qada dalam rukun iman yang keenam ini adalah keputusan dan kepastian yang Allah putuskan/pastikan terhadap seluruh makhluk ciptaan-Nya sejak zaman 'azali. Yakni sebelum alam ini diciptakan.

Dalam bahasa yang paling sederhana, qada adalah ketetapan dan keputusan Allah sejak zaman azali, sedangkan qadar/takdir adalah ketetapan/ketentuan Allah yang berjalan mengikuti qada-Nya sesudah zaman azali, yakni dari awal kehidupan di dunia ini sampai di akhirat nanti. (59)

Qada adalah aturan umum tentang sesuatu menurut hukum tertentu, sedangkan qadar adalah ketentuan sebagai akibat pelaksanaan hukum tertentu. Dapat pula dikatakan bahwa qada adalah ketentuan, sedangkan qadar adalah pelaksanaan ketentuan itu. Dengan demikian, qada dan qadar adalah aturan umum yang dilaksanakan menurut ukuran atau ketentuan takwanya. (65)

Kaelany (2000:67) perkataan " $W a$ tu'minu bi-l-qadri khairihi wa syarrihi" (beriman kepada qadar baik dan jahat/buruknya) terdapat dalam hadis yang bersumber dari Umar ra. Dan diriwayatkan oleh Muslim. Yang lengkapnya menyebutkan:

"Kabarkan kepadaku tentang iman (kata Jibril) Nabi (Muhammad Shallallahu 'Alaihi Wa Sallam) bersabda: "Engkau beriman kepada Allah, malaikatmalaikat-Nya, kitab-kitab-Nya, rasulrasul-Nya, hari akhirat, dan beriman kepada takdir (baik dan buruk-Nya)." (20)

Lebih lanjut, Nashir bin Abdullah Al Qafari (2001:124) bahwa qadar (ketentuan Allah pada makhluk-Nya) adalah rahasia Allah pada ciptaan-Nya. Ia tidak akan diketahui oleh malaikat yang paling dekat dengan-Nya dan Nabi yang diutus-Nya. Upaya untuk mendalami dan meneliti hal tersebut merupakan sesuatu yang hina, haram, dan sesat. Berhatihatilah untuk meneliti dan memikirkannya. Karena hal itu bisa mengakibatkan keragu-raguan dalam hati.

Qada qadar yang sering dikenal dengan istilah (takdir) bisa juga berwujud ketentuan-ketentuan tertulis (dalam kitab) dan bisa berupa hukum-hukum dalam alam semesta ini (apa yang dikenal nature of laws hukum alam atau sunnatullah). Percaya kepada takdir ini memberikan motivasi agar kita berupaya semaksimal mungkin untuk berusaha menurut hukumhukum Tuhan itu.

Lebih lanjut, beriman kepada qada dan qadar, ialah setiap manusia (muslim dan muslimat) wajib mempunyai niat dan keyakinan sungguh-sungguh bahwa segala perbuatan makhluk, sengaja 
maupun tidak telah ditetapkan oleh Allah Subhanahu wata'ala.

Sejak zaman azali, ketentuan itu telah ditulis di dalam Lauh Mahfuz (lembaran yang terpelihara). Jadi, semua yang akan terjadi sedang atau sudah terjadi) di dunia ini semuanya sudah diketahui oleh Allah Subhanahu wata'ala. jauh sebelum hal itu sendiri terjadi.

Sebagaimana firman Allah Subhanahu yang maknanya: "Tiada suatu bencanapun yang menimpa di bumi dan (tidak pula) pada dirimu sendiri melainkan telah tertulis dalam kitab (Lauhul Mahfuzh) sebelum Kami menciptakannya.Sesungguhnya yang demikian itu adalah mudah bagi Allah." (QS. Al-Hadid:22)

Mengenai ayat tersebut, Ibnu Abbas r.a. berkata, Sudah dituliskan sebelum terjadinya musibah itu." Kaum mukmin pun wajib berikhtiar dan berusaha sekuat tenaga meskipun telah beriman dan mempercayai benar-benar bahwa semua ketentuan datangnya dari Allah Subhanahu wa ta'ala. agar lepas dari ketentuan jelek dan buruk serta berjuang hanya mendapatkan ketentuan yang baik saja. (31)

Allah Subhanahu wa ta'ala. mengatur segala sesuatu dengan kebijaksanaan dan kehendak-Nya. Apa saja yang terjadi di alam semesta, berjalan sesuai dengan kehendak Allah dan mengikuti peraturanperaturan yang telah ditetapkan-Nya. Allah Subhanahu wa ta'ala. mengetahui apa saja yang akan terjadi atas segala sesuatu. (34)

ada beberapa hal yang terjadi dan sempurna dengan semata kodrat yang tertinggi, dan menurut semata kehendak Ilahi, dan ia berlaku pada manusia biar mereka suka atau tidak, dan tidak peduli apakah mereka menyadarinya atau tidak menyadarinya.

Maka akal dengan kadar kepandaian atau kebodohan yang tersimpan di dalamnya, watak tabiat berupa ketenangan atau kebesaran bentuk tubuh dari yang tinggi atau rendah, cantik atau jelek, kepribadian dari yang bersifat optimis atau pesimis, waktu saat mereka dilahirkan, tempat di mana mereka dibesarkan, lingkungan di sekeliling mereka, orang tua yang melahirkan mereka, naluri dan bakat yang mereka sambut dari keduanya, dan seterusnya soal hidup dan mati, sehat dan sakit, kehidupan yang lapang dan yang sulit dan sebagainya, semuanya itu harus mereka terima bagaimana adanya. Maka jari jemari takdirlah sendirinya yang bergerak baik lahir maupun batin untuk mengarahkan kehidupan kepada arah yang dikehendaki oleh Pemilik kehidupan itu, yang maknanya: "Sesungguhnya bagi Allah tidak ada satupun yang tersembunyi di bumi dan tidak (pula) di langit. Dialah yang membentuk kamu dalam rahim sebagaimana dikehendakiNya. tak ada Tuhan (yang berhak disembah) melainkan Dia, yang Maha Perkasa lagi Maha Bijaksana. (QS. Ali 'Imran:5-6) (32)

Oleh karena itu, akal adalah potensi yang dianugerahkan Allah kepada manusia, yang (dengan akalnya itu) memungkinkan manusia memperoleh dan mengembangkan berbagai ilmu pengetahuan. Dengan akalnya, manusia dapat membedakan yang benar dengan yang salah, yang baik dan buruk, yang menyelamatkan dan yang menyesatkan.

Dan, akal yang diberi tempat yang tinggi dalam agama Islam itu, mendorong kaum muslimin memahami agama dan ajaran Islam dengan menggunakan penalaran rasional, sejauh ajaran itu memang menjadi wewenang akal untuk memikirkannya seperti tentang alam semesta, diri sendiri, umat terdahulu, pranata (lembaga-lembaga) sosial dan sebagainya. (29) Dengan potensi akal ini, manusia bisa berartikulasi, menyusun proposisi, berpendapat, berargumentasi, analogi, menyimpulkan dan mengambil keputusan. (61)

2. Ibadah dalam Praktik Ritual Mandi Safar Pada Masyarakat Melayu Sungai Jambu di Kayong Utara

Pada pembahasan ini menyajikan teori-teori yang mendukung data yang telah diperoleh di lapangan.

Ritual Mandi Safar Oleh Masyarakat Melayu Sungai Jambu di Kayong Utara bahwa dalam pelaksanaan tradisi tersebut yakni berwudhu, membaca surat Al-Fatihah, surat al-Ikhlas, surat al-Falak, surah an-Naas, (berzikir yakni membaca Laa 
ilaha illallah Wallahu Akbar) surah alFalak, shalawat, menolong antara sesama manusia, do'a selamat, do'a minta panjangkan umur, dan do'a tolak bala.

Ibadah adalah sikap tunduk patuh dan merendah kepada sesuatu yang dipercayai memiliki sifat-sifat ketuhanan (Uluhiyah/Rububiyah) serta kemandirian penuh dalam segala perbuatannya. (56) Menurut Muhammad Daud Ali (2004:244) Ibadah menurut bahasa artinya taat, tunduk, turut, ikut, dan do'a.

Pendapat yang demikian juga dikemukakan (42) Do'a, yaitu meminta kepada Allah apa saja yang diinginkan dengan cara yang baik sebagaimana yang dicontohkan oleh Rasulullah Shallallahu 'Alaihi Wa Sallam. Do'a adalah cara membuktikan kelemahan manusia dihadapan Allah, karena itu berdoa merupakan inti dari beribadah. (15)

Berdo'a dengan sendirinya merupakan ibadah. Do'a pun bisa dipandang sebagai pintu yang besar di antara pintu-pintu ibadah yang lain, dalam memperhambakan diri kepada Allah Subhanahu wa ta'ala dan memperlihatkan ketundukkan jiwa kepada-Nya. Tidak mengherankan jika ada hadis yang menyatakan:

$$
\text { الدعاء مخ العبادة \}رواه لترمذي\{ }
$$

"Do'a itu adalah otaknya ibadah," (HR Tirmidzi).

Pendapat yang sama dikemukakan oleh Al-Ghazali (1997: 46-47) bahwa Nabi Muhammad Shallallahu 'Alaihi Wa Sallam pernah bersabda : “Do'a itu adalah ibadah." (Diriwayatkan Nu'man bin Basyir). Kemudian beliau membaca firman Allah Subhanahu wa ta'ala: "Berdo'alah kepada-Ku, niscaya akan Ku-Kabulkan bagimu." Sabda beliau pula:

$$
\text { لاعاء العبادة }
$$

"Do'a itu adalah otaknya ibadah," (Diriwayatkan oleh Tirmidzi, dari Anas). (58)

Lebih lanjut (48) konsep doa dalam al Quran merupakan permintaan, permohonan, pujian, percakapan, ibadah, seruan atau ajakan, yang hanya tertuju pada Allah SWT semata, sang pencipta alam semesta. Karena didasari atas keimanan dan rasa ketidakberdayaan dalam diri seorang muslim. (48)

Lebih lanjut, dengan do'a akan tercapai keinginan dan cita-cita. (28)

Pendapat demikian dikemukakan oleh (30) bahwa pengetahuan tentang segala yang gaib dan segala yang akan terjadi hanya ada pada Allah Subhanahu wa ta'ala. Apa yang akan terjadi dan menimpa seseorang manusia pada waktu akan datang, tidak ada yang mengetahui kecuali Allah Subhanahu wa ta'ala, karena Dia-Lah yang menghendaki dan menentukanNya. Oleh karena itulah, maka manusia diperintah berusaha dan berikhtiar semampu mungkin, sambil berdo'a dan bertawakkal agar mendapatkan yang terbaik. (30)

Menurut Mahjuddin, (21) Ibadah dalam Islam itu adakalanya bersifat murni (mahdah) berupa ritualitas khusus dan rutin, adakalanya bersifat tidak murni (ghair mahdah). Ibadah mahdah adalah ibadah yang berkaitan langsung dengan hubungan Allah sebagai Tuhan-nya dengan Manusia sebagai hamba-Nya, seperti shalat, zakat, puasa, haji yang semuanya telah ditentukan waktu pelaksanaannya serta petunjuk teknisnya oleh Allah dan Rasul-Nya di dalam Al-Quran dan hadits Nabi Saw. Adakalanya ibadah mahdah tidak dicantumkan waktunya, seperti dzikir, baca Al-Quran, dan bertafakkur yang termasuk dari kategori ibadah murni. Dan ibadah ghairu mahdah adalah ibadah yang berkaitan langsung manusia dengan sesamanya, dengan hewan-hewan, dan lain sebagainya. (53)

Pendapat yang hampir sama yakni dikemukakan Muhaimin, dkk (dalam (18) bahwa Ibadah dalam arti khusus adalah ibadah yang berkaitan dengan arkan al-Islam, seperti syahadat, shalat, zakat, puasa, dan haji, bersuci dari hadas kecil maupun besar, wajib 'ain dan wajib kifayah". (17) 
Lebih lanjut, (26) Shalawat Nabi merupakan satu kesatuan dalam sistem ajaran Islam. Dalam sebagian besar ritual Islam, penggunaan shalawat menjadi keharusan. Kewajibankewajiban itu antara lain terdapat dalam ritual ibadah mahdlah seperti shalat, khotbah Jum'at, doa, dan sebagainya. (27)

Ibadah dapat dibagi ke dalam lima kategori, yaitu 1) ibadah dalam bentuk perkataan atau lisan, seperti berzikir, berdo'a, memuji Allah dengan mengucapkan alhamdulillah, dan membaca Al-Qur'an, 2) ibadah dalam bentuk perbuatan yang tidak ditentukan bentuknya, seperti membantu orang lain, 3) ibadah dalam bentuk pekerjaan yang telah ditentukan wujudnya seperti shalat, zakat, puasa, dan haji, 4) ibadah yang caranya dan pelaksanaannya berbentuk menahan diri, seperti puasa, i'tikaf, ihram, 5) ibadah yang sifatnya menggugurkan hak, misalnya memaafkan orang lain yang telah melakukan kesalahan, atau membebaskan orang yang berhutang dari kewajiban membayarnya. (29)

Ibadah terdiri dari beberapa bagian, yakni ibadah yang wajib dilaksanakan secara terang-terangan, sebagaimana adzan, iqamah, takbir, mengeraskan suara dalam shalat atau khutbah, amar ma'ruf nahi 'anil munkar, mendirikan shalat berjamaah atau Jum'ah, shalat hari raya, jihad, menjenguk orang sakit, mengiringi janazah dan lain sebagainya. (57)

Mengenai pembahasan zikir, orang yang berzikir yakin bahwa menolong orang lain dan bahkan makhluk lainnya (menjaga dan memelihara alam semesta) adalah ibadah. (33) Rasulullah Shallallahu 'Alaihi Wa Sallam telah mengutamakan ucapan Laa ilaha illallah semua macam zikir. Oleh sebab itu, kita memohon dari Allah Subhanahu wata'ala agar menjadikan kita pada saat-saat terakhir hidup kita termasuk para ahli Laa ilaha illallah, dalam ucapan dan keseluruhan diri kita, secara lahir dan batin. Itulah beberapa rahasia yang mengisyaratkan kepada pelbagai makna zikir. (6)
Pembagian ibadah salah satunya adalah takbir, tahmid, tasbih, tahlil, taslim, khutbah yang disyari'atkan, memberi salam dan membalasnya, perintah wajib dan mandub, mencegah perbuatan haram atau makruh, bertanya persoalan yang wajib, memberi fatwa, memberi hukum, memberikan kesaksian, adzan, iqamah, membaca Al-Qur'an, membaca basmallah menjelang makan atau minum dan tatkala menyembelih kurban atau binatang lainnya atau menjelang membaca Al-Qur'an dan ketika takut atau ada gangguan syetan. Selanjutnya pada halaman (429) ibadah terdiri atas beberapa macam, yakni ucapan yang khusus bagi Allah, seperti tasbih, taqdis, tahmid, tahlil, takbir dan puji-pujian lainnya. (57)

Rasulullah Shallallahu 'Alaihi Wa Sallam bersabda:

"Barang siapa bertasbih (mengucapkan subhanallah) selepas tiap shalat, sebanyak tiga puluh kali, bertahmid (membaca alhamdulillah) sebanyak tiga puluh kali, dan bertakbir (mengucapkan Allahu Akbar) tiga puluh kali, kemudian menutupnya dengan membaca (Laa ilaha illallahu wahdahu la syarika lahu'l mulku wa lahu'l-hamdu, wa hua 'ala kulli syai-in qadir) maka akan terampuni baginya semua dosanya walaupun sebanyak buih lautan." (Dirawikan oleh Muslim, dari Abu Hurairah) (6)

3. Akhlak dalam Praktik Ritual Mandi Safar Pada Masyarakat Melayu Sungai Jambu di Kayong Utara

Pada pembahasan ini peneliti akan menyajikan teori-teori yang mendukung data yang telah diperoleh di lapangan.

Masyarakat Melayu Sungai Jambu di Kayong Utara bahwa tokoh agama dan ketua adat (sekaligus berperan sebagai tokoh agama) membantu masyarakat membaca surat-surat yang terdapat dalam al-Qur'an, silaturrahim, beserta do'a selamat, do'a minta panjangkan umur, dan tolak bala'. Ketupat, lontong dan berbagai jenis makanan yang di makan secara bersama-sama di 
halaman masjid kemudian dibagikan kepada sesamanya, mencuci piring dan merapikan tikar maupun terpal sebagai alas duduk secara bersama-sama serta membersihkan dan menjaga kelestarian lingkungan.

Dalam surat An-Nisa' ayat 36 yang artinya "Sembahlah Allah dan janganlah kamu mempersekutukanNya dengan sesuatupun. dan berbuat baiklah kepada dua orang ibu-bapa, karib-kerabat, anak-anak yatim, orang-orang miskin, tetangga yang dekat dan tetangga yang jauh, dan teman sejawat, Ibnu sabil dan hamba sahayamu. Sesungguhnya Allah tidak menyukai orang-orang yang sombong dan membangga-banggakan diri." (Q.S. An-Nisa':36) (51)

Akhlak secara etimologis, yaitu kata akhlak berasal dari bahasa Arab, jamak dari "Khuluqun" yang menurut bahasa berarti budi pekerti, perangai, tingkah laku atau tabiat. (5) Akhlak adalah hasil dari pendidikan, latihan, pembinaan dan perjuangan keras dan sungguh-sungguh. (38)

Dalam Islam, akhlak memiliki posisi yang sangat penting, yaitu sebagai salah satu rukun agama Islam. Dalam kaitan ini, Rasulullah Shallallahu "Alaihi Wa Sallam. pernah ditanya," Beragama itu apa?" Beliau menjawab, "Berakhlak yang baik" (H.R. Muslim). Pentingnya kedudukan akhlak dapat dilihat ketika melihat bahwa salah satu sumber akhlak adalah wahyu. Nabi Muhammad Shallallahu 'Alaihi Wa Sallam. pun mengabarkan bahwa orang yang paling sempurna keimanannya diantara umatnya adalah yang paling baik akhlaknya. Dengan demikian, seyogianya seorang muslim berusaha dan bersemangat untuk memiliki akhlak yang baik dan merujuk kepada Rasulullah Shallallahu 'Alaihi Wa Sallam. dalam berakhlak. (47)

Dalam Islam, dasar atau alat pengukur yang menyatakan baik buruknya sifat seseorang itu adalah AlQur'an dan As-Sunnah Nabi Shallallahu 'Alaihi Wa Sallam. Apa yang baik menurut Al-Qur'an dan AsSunnah, itulah yang baik untuk dijadikan pegangan dalam kehidupan sehari-hari. Sebaliknya, apa yang buruk menurut Al-Qur'an dan AsSunnah, itulah yang tidak baik dan harus dijauhi. (47)

Tuhan mengajarkan kepada manusia, bagaimana cara berakhlak kepadaNya, antarsesama dan lingkungan. Oleh sebab itulah manusia diciptakan supaya mempelajari akhlak mahmudah dan meninggalkan akhlak mazmumah. (38)

"Perbuatan baik mesti dikerjakan dan yang buruk mesti dihindarkan, karena yang baik pasti mendatangkan kemanfaatan, sedangkan yang buruk pasti berimplikasi kepada kemudharatan. (38)

Sifat yang tertanam dalam jiwa, yang dengannya lahirlah macam-macam perbuatan, baik atau buruk, tanpa membutuhkan pemikiran dan pertimbangan. (5) Akhlak adalah kebiasaan kehendak. Ini berarti bahwa kehendak itu bila dibiasakan akan sesuatu maka kebiasaannya itu disebut akhlak. Contohnya, bila kehendak itu dibiasakan memberi, maka kebiasaan itu ialah akhlak dermawan. (7)

Akhlak adalah suatu kekuatan dalam kehendak yang mantap, kekuatan dan kehendak berkombinasi membawa kecenderungan pada pemilihan pihak yang benar (dalam hal akhlak yang baik) atau pihak yang jahat (dalam hal akhlak yang jahat). (64)

Akhlak adalah budi pekerti, watak, kesusilaan (kesadaran etik dan moral) yaitu kelakuan baik yang merupakan akibat dari sikap jiwa yang benar terhadap Khaliknya dan terhadap sesama manusia. (7)Akhlak adalah sifat yang melekat dalam jiwa seseorang yang menjadikan ia dengan mudah bertindak tanpa banyak pertimbangan lagi”. Atau boleh juga dikatakan, perbuatan yang sudah menjadi kebiasaan.

Orang yang pemurah sudah biasa memberi. Ia memberi itu tanpa banyak pertimbangan lagi. Seolah-olah tangannya sudah terbuka lebar untuk itu. Hal ini bisa terjadi karena yang bersangkutan sebelumnya telah berlatih, artinya sifat pemurah itu 
sudah biasa dilakukan setiap saat. Begitu juga orang kikir. Seolah-olah tangannya sudah terpaku saja dalam kantongnya, tidak mau keluar mengulurkan bantuan kepada fakirmiskin. Begitu juga orang yang pemarah selalu saja marah tanpa ada alasan yang jelas. (64)

"Akhlak adalah mustika hidup yang membedakan makhluk manusia dari makhluk hewani. Manusia tanpa akhlak adalah manusia yang telah "membinatang", sangat berbahaya. Ia akan lebih jahat dan lebih buas daripada binatang buas sendiri. Dengan demikian, jika akhlak telah lenyap dari diri masing-masing manusia, kehidupan ini akan kacau balau, masyarakat akan menjadi berantakan. Orang tidak lagi peduli soal baik atau buruk, halal atau haram." (64)

"Akhlak ialah suatu perbuatan yang timbul yang merupakan gambaran jiwa dengan melakukannya menjadi kebiasaan tanpa dipaksa, tanpa dipikir dan tanpa diteliti. Yang menjadi ukuran standar adalah menetapkan segala perbuatan yang baik atau buruk yang benar atau salah dan yang hak atau batil. Tapi yang dimaksud dalam pengertian disini adalah akhlak yang baik." (2)

"Akhlak adalah perbuatan yang disadari oleh si pelaku." Sedangkan menurut Amru Khalid menegaskan, "Sesungguhnya akhlak lebih penting daripada semua itu. Sesungguhnya tujuan utama dari setiap ibadah yang terus dilakukan adalah untuk menata akhlak. Jika ibadah tidak membawa kepada ketertataan akhlak, maka bisa dikatakan bahwa ibadah hanya sekedar gerak tubuh tanpa makna." (36)

"Islam juga menghargai pendapat akal pikiran yang sehat yang sejalan dengan al-Qur'an dan al-Sunnah. Peranan akal pikiran dalam ajaran Islam demikian besar dan dihargai adanya, termasuk peranannya dalam menjabarkan masalah akhlak. Ajaran akhlak yang berdasarkan al-Qur'an dan al-Sunnah bersifat absolut dan universal serta mutlak, yakni tidak dapat ditawar-tawar lagi dan akan berlangsung sepanjang zaman. Namun dalam penjabaran al-Qur'an yang absolut, mutlak dan universal itu diperlukan akal pikiran manusia.

Hasil pemikiran akal terhadap maslah yang absolut itu bentuknya berbeda-beda sesuai dengan keadaan masyarakat atau sesuai dengan yang diakui masyarakat. Dengan cara demikian ajaran akhlak dalam Islam dapat diterima oleh seluruh masyarakat berdasarkan hasil ijtidah akal pikiran. Sebagai contoh menutup aurat adalah merupakan akhlak yang bersifat absolut, mutlak dan universal, tetapi bagaimana cara dan bentuk menutup aurat itu dapat berbeda-beda. Untuk menentukan cara dan bentuk menutup aurat tersebut diperlukan pemikiran akal yang sehat." (3)

Akhlak mencakup jasmani dan rohani, lahir dan bathin, dunia dan akhirat, bersifat universal, berlaku sepanjang zaman dan mencakup hubungan dengan Allah, manusia dan alam lingkungan. (60)

Ruang lingkup akhlak dalam Islam ada tiga, yakni mencakup akhlak manusia dengan Allah Subhanahu wa ta'ala, akhlak manusia dengan sesama manusia, dan akhlak manusia dengan makhluk lain. (59)

"Ruang lingkup akhlak secara umum adalah meliputi 3 bidang yaitu:

1. Akhlak kepada Allah antara lain adalah:

a. Mensyukuri nikmat dan karunia Allah.

b. Berserah diri kepada Allah.

2. Akhlak terhadap manusia

a. Akhlak terhadap tetangga antara lain saling mengunjungi, saling memberi, saling menghormati

b. Akhlak terhadap masyarakat antara lain memuliakan tamu dan menghormati nilai dan norma yang berlaku di masyarakat. Menurut Hasan (dalam Rosihon Anwar, 2008: 243) orang mukmin akan tergerak hatinya apabila melihat orang lain tertimpa kerusakan untuk menolong mereka sesuai dengan kemampuannya. Apabila tidak ada bantuan berupa benda, 
kita dapat membantu orang tersebut dengan nasihat atau kata-kata yang dapat menghibur hatinya. Bahkan, sewaktu-waktu bantuan jasa pun lebih diharapkan daripada bantuanbantuan lainnya.

3. Akhlak terhadap bukan Manusia (lingkungan hidup) antara lain;

a. Sadar dan memelihara kelestarian lingkungan hidup,

b. Menjaga dan memanfaatkan alam terutama hewani, nabati, flora dan fauna.

c. Sayang kepada sesama makhluk." (29)

Selain itu, contoh-contoh akhlak karimah antara lain:

1. Akhlak terhadap Allah

2. Akhlak terhadap diri sendiri

3. Akhlak terhadap orang lain

4. Akhlak terhadap alam semesta (lingkungan) (20)

"Saling membantu dan saling tolong-menolong menjadi penting dalam mencapai masyarakat madani. Itu sebabnya, Nabi menganjurkan kehidupan sesama Muslim itu laksanakan kehidupan bersaudara. Dalam al-Qur'an disebutkan, bahwa kaum muslimin itu adalah bersaudara. Akhlak antar sesama, merupakan bagian dari ketakwaan seseorang. Dalam hadis di bawah ini, ada tiga perintah, yaitu bertakwalah kepada Allah, ikuti yang buruk itu dengan yang baik dan berprilaku baik antarsesama manusia.

Hadis Nabi Muhammad alMushthafa:

Artinya: "Abu Dzar bertanya kepada Rasulullah Shallallahu 'Alaihi Wa Sallam, wahai Rasulullah Shallallahu 'Alaihi Wa Sallam. berilah saya washiyat (pengajaran). Kemudian Rasulullah menjawab: Bertakwalah kepada Allah di mana saja kamu berada. Lalu Abu Dzar bertanya lagi, "Tambah lagi ya Rasul." Kemudian Rasulullah menjawab: Ikutilah kejelekan dengan kebaikan, maka kebaikan tersebut akan menghapus kejelekan. Lalu Abu Dzar berkata lagi,"Tambah lagi ya Rasul: Kemudian Rasulullah menjawab: Berakhlaklah dengan manusia dengan akhlak yang baik." (HR al-Tirmiziy) (38)

"Dalam hadist-hadistnya, Rasulullah Shallallahu 'Alaihi Wa Sallam banyak menyeru kita untuk tolong-menolong atau bahu membahu. Dengan demikian, akan terbentuk masyarakat yang kokoh laksana benteng yang masing-masing komponennya saling menguatkan, atau laksana satu tubuh yang jika salah satu bagian sakit maka yang lain juga akan ikut merasakan. Rasulullah Shallallahu 'Alaihi Wa Sallam. bersabda,

Artinya: "Siapa saja (di antara orangorang mukmin) yang melapangkan satu kesusahan dunia yang dialami mukmin yang lain maka Allah Subhanahu wata'ala. akan melapangkan satu kesusahan darinya di hari akhirat. Siapa saja yang menutup aib (kejelekan) seorang muslim maka Allah Subhanahu wata'ala. juga akan menutup aibnya, baik di dunia maupun di akhirat. Sesungguhnya Allah Subhanahu wata'ala. akan selalu menolong seorang hamba selama ia tetap menolong saudaranya (sesama muslim)." (HR Tirmidzi) (50)

\section{Metodologi Penelitian}

\section{Ragam Penelitian}

Dalam penelitian ini peneliti menggunakan metode kualitatif dengan pendekatan etnografi dimana semua data, informasi dan fakta yang diperoleh di lapangan, setelah dikumpulkan kemudian dianalisis sesuai dengan realita yang ada, karena penelitian yang dilakukan sesuai dengan gejala- gejala yang tampak berdasarkan fenomenafenomena yang ada. 
Secara historis cara-cara sebagaimana dilakukan dalam metode kualitatif, sebagai ethnos (menunjuk pada manusia, ras, dan kelompok kebudayaan), sudah ada sejak zaman Yunani. (44)

Kualitatif adalah metode yang pada gilirannya menghasilkan data deskriptif dalam bentuk kata-kata, baik tertulis maupun lisan. (44)

"Peneliti kualitatif pergi kelapangan dan mengamati dan terlibat secara intensif sampai ia menemukan secara utuh apa yang dimaksudnya. Setiap peneliti datang dan memotret keadaan yang terjadi peneliti langsung mencatat dan menginterpretasikannya dengan menggunakan teknik-teknik yang dapat memudahkan memahami keseluruhan dari bagian-bagian penelitiannya. (14)

"Kriteria data dalam penelitian kualitatif adalah data yang pasti. Data yang pasti adalah data yang sebenarnya terjadi sebagaimana adanya, bukan daya yang sekedar yang terlihat, terucap, tetapi data yang mengandung makna di balik yang terlihat dan terucap tersebut. Penelitian kualitatif digunakan untuk mendapatkan data yang mendalam, suatu data yang mengandung makna. Makna adalah data yang sebenarnya, data yang pasti yang merupakan suatu nilai di balik data yang tampak. Oleh karena itu dalam penelitian kualitatif tidak menekankan pada generalisasi, tetapi lebih menekankan pada makna. (54)

Pendekatan yang dilakukan menggunakan metode etnografi. Etnografi adalah suatu kebudayaan yang mempelajari kebudayaan lain. Etnografi bermakna untuk membangun suatu pengertian yang sistemik mengenai semua kebudayaan manusia dari perspektif orang yang telah mempelajari kebudayaan itu. Deskripsi kebudayaan, sebagai tugas utama dari etnografi, merupakan langkah pertama dalam memahami maupun manusia. (52)

Oleh karena itu, lima manfaat etnografi dalam memahami rumpun manusia, yaitu: a) memberikan informasi tentang adanya teori-teori ikatan budaya (culture-bound), sekaligus mengoreksi teori sosial Barat, b) menemukan teori grounded, sekaligus mengoreksi teori formal, c) memahami masyarakat kecil, (non Barat), sekaligus masyarakat kompleks (Barat), d) memahami perilaku manusia, sebagai perilaku yang bermakna, sekaligus perbedaannya dengan perilaku binatang, dan e) yang terpenting adalah untuk memahami manusia sekaligus kebutuhan-kebutuhannya. (44)

Adapun pendekatan etnografi yaitu:

a. Menetapkan informan

b. Mewawancarai informan

c. Membuat catatan etnografis

d. Mengajukan pertanyaan deskriptif

e. Melakukan analisis wawancara

f. Membuat analisis domain

g. Mengajukan pertanyaan struktural

h. Membuat analisis taksonomik

i. Mengajukan pertanyaan kontras

j. Membuat analisis komponen

k. Menemukan tema-tema budaya

1. Menulis suatu etnografi. (52)

\section{Ruang Lingkup/Wilayah Penelitian}

Penelitian dilaksanakan di Kayong Utara, tepatnya di Sungai Jambu. Ritual Mandi Safar memang menyebar di berbagai Desa di Kayong Utara. Namun, peneliti memilih penelitian di Sungai Jambu dikarenakan sebagai berikut:

a. Peneliti telah mengenal betul dusun tersebut sehingga untuk memperoleh informasi dan memasuki setting penelitian dapat dilaksanakan dengan mudah.

b. Sungai Jambu tidak begitu luas, sehingga mudah dijangkau dan mengefisienkan tenaga, waktu, dan biaya.

\section{Penentuan Sumber Data Penelitian}

Sumber data primer diperoleh dari tokoh agama dan ketua adat sedangkan data sekunder peneliti peroleh dari warga setempat yang ikut melaksanakan Ritual Mandi Safar. Adapun informan yang dimaksud adalah sebagai berikut:

a. Tokoh agama, yaitu orang yang dianggap mengerti dan memahami masalah agama serta memiliki kualitas keilmuan yang mendalam dan memahami tentang Ritual Mandi Safar. Selain itu juga dituakan dan sangat dihormati oleh masyarakat setempat. Tokoh agama berjumlah 3 
orang. Salah satu di antara mereka juga berperan sebagai tokoh adat.

b. Ketua adat (berperan sebagai tokoh agama) yaitu orang yang memahami dan mengetahui masalah Ritual Mandi Safar. Ketua adat ini sekaligus juga berperan sebagai tokoh agama dan hanya berjumlah satu orang, serta warga yang ikut Mandi Safar.

c. Pengurus Masjid

d. Warga yang ikut melaksanakan Ritual Mandi Safar.

\section{Pemilihan Konteks (Setting)}

Penelitian ini dilakukan di Kayong Utara, yaitu di Sungai Jambu. Tahap awal peneliti melakukan wawancara dengan tokoh agama, ketua adat (berperan sebagai tokoh agama), pengurus masjid, dan warga. Peneliti melakukan wawancara di rumah mereka. Waktu yang tepat untuk melakukan wawancara adalah setelah shalat dzuhur, maghrib, ataupun Isya, karena mereka adalah petani. Caranya peneliti terlebih dahulu menghubungi lewat handphone dan kemudian jika diperbolehkan wawancara.

Kemudian melakukan observasi. Observasi dilakukan pada saat tokoh agama sekaligus ketua adat (berperan sebagai tokoh agama) menyiapkan peralatan yaitu menuliskan tujuh ayatayat Al-Qur'an yang terdiri dari empat surat pada daun andung-andung yang disebut dengan salamun tujuh (tujuh kesejahteraan). Kemudian peneliti mengobservasi proses pelaksanaan Ritual Mandi Safar di halaman masjid dan saat acara mandi di parit.

\section{Teknik Pengumpulan Data}

Metode pengumpulan data yang digunakan dalam penelitian ini sebagai berikut:

a. Observasi

"Observasi adalah pengamatan terhadap suatu objek yang diteliti baik secara langsung maupun tidak langsung untuk memperoleh data yang harus dikumpulkan dalam penelitian." (14)

Hal-hal penting dalam observasi tidak lain karena observasi berkaitan dengan permasalahan berikut. Pertama, tidak ada pengamatan dua orang sama. Betapapun dilatih, pengamatan dua orang selalu ada saja perbedaannya.

Apa yang kita amati adalah ekspresi pribadi kita, yang dipengaruhi oleh latar belakang pendidikan, pengalaman, pengetahuan, perasaan, nilai-nilai, harapan, dan tujuan kita. Kedua, mengadakan pengamatan bukan proses pasif dimana kita hanya mencatat apa yang terjadi seperti halnya dengan kamera, seakan-akan kita berada di luar dan terpisah dari dunia yang kita amati. Mengadakan observasi adalah proses aktif. (14) Observasi merupakan suatu proses yang kompleks, suatu proses yang tersusun dari berbagai proses biologis dan psikologis. Dua diantara yang terpenting adalah proses pengamatan dan ingatan. (54)

"Observasi adalah kegiatan keseharian manusia dengan menggunakan panca indra mata sebagai alat bantu utamanya selain panca indra lainnya seperti telinga, penciuman, mulut dan kulit. Karena itu, observasi adalah kemampuan seseorang untuk menggunakan pengamatannya melalui hasil kerja panca indra mata serta dibantu dengan panca indra lainnya." Dari pemahaman observasi di atas, sesungguhnya yang dimaksud dengan observasi adalah metode pengumpulan data yang digunakan untuk menghimpun data penelitian melalui pengamatan dan pengindraan. (8)

Dalam penelitian ini menggunakan observasi non partisipan, yaitu peneliti sebagai pengamat tidak terlibat secara langsung dalam kegiatan yang dilakukan oleh objek. Peneliti hanya sekedar mengamati dan mencari data yang diperlukan dalam penelitian ini. "Observasi non partisipan adalah observasi pengumpulan data dan informasi tanpa melibatkan diri, atau tidak menjadi bagian dari lingkungan sosial/organisasi yang diamati." (46)

Observasi tidak langsung yaitu observasi yang dilakukan terhadap suatu objek melalui perantaraan 
suatu alat atau cara, baik dilaksanakan dalam situasi sebenarnya maupun buatan. (25)

Jenis observasi ini dipilih karena peneliti bukan merupakan dari subyek yang diteliti melainkan hanya sebagai observer tidak ikut dalam kehidupan orang yang diobservasi dan secara terpisah berkedudukan selaku pengamat. Sedangkan data yang digunakan dalam teknik observasi non partisipan ini adalah pedoman observasi, catatan lapangan, foto dan video. Dalam teknik observasi non partisipan ini peneliti memperoleh data khususnya tentang akidah, ibadah, dan akhlak dalam Ritual Mandi Safar.

b. Wawancara

"Wawancara adalah "proses memperoleh keterangan untuk tujuan penelitian dengan cara tanya jawab sambil bertatap muka antara si penanya (pewawancara) dengan si penjawab (responden atau informan) dengan menggunakan alat yang dinamakan pedoman wawancara. Wawancara merupakan proses interaksi antara pewawancara dengan responden. (10)

Wawancara secara garis besar dibagi dua, yakni wawancara tak terstruktur dan wawancara terstruktur. Wawancara tak terstruktur sering juga disebut wawancara mendalam, wawancara intensif, wawancara kualitatif, dan wawancara terbuka (open ended interview), wawancara etnografis, sedangkan wawancara terstruktur sering juga disebut wawancara baku (standardized interview), yang susunan pertanyaannya sudah ditetapkan sebelumnya (biasanya tertulis) dengan pilihan-pilihan jawaban yang juga sudah disediakan. (13)

Wawancara dibedakan menjadi dua macam, yakni wawancara terstruktur dan wawancara tak terstruktur. Wawancara pertama juga sering disebut wawancara baku, terarah, terpimpin, di dalamnya susunan pertanyaan sudah ditentukan sebelumnya, sedangkan wawancara kedua juga disebut wawancara mendalam, intensif, dan terbuka.

Data dalam wawancara terstruktur ditempatkan dalam konteks independen, lepas dari konteks, sedangkan dalam wawancara tak struktur data terkandung dalam konteks sosial itu sendiri. Artinya, informasi diperoleh dari kata-katanya sendiri dan dengan sendirinya merupakan subjektivitas informan. (44)

Wawancara tidak terstruktur memberi peluang kepada peneliti untuk mengembangkan pertanyaanpertanyaan penelitian. Meski disebut wawancara tidak berstruktur bukan berarti dialog-dialog yang ada lepas begitu saja dari konteks, inilah yang terutama harus diperhatikan peneliti yang menggunakan wawancara ini. Sejak awal penelitian ini memilih fokus pembicaraan yang ingin ditanyakan, sehingga seluruh wawancara yang dilakukan diarahkan pada fokus yang telah ditentukan. (35)

Dalam wawancara ini, menggunakan teknik wawancara mendalam tak terstruktur.

Wawancara mendalam (in-depth interview) adalah proses memperoleh keterangan untuk tujuan penelitian dan cara tanya jawab sambil bertatap muka antara pewawancara dengan informan atau orang yang diwawancarai. (19)

Wawancara ini peneliti lakukan secara individual mulai dari tokoh agama hingga tokoh adat (sekaligus berperan sebagai tokoh agama. Dalam melakukan wawancara mendalam membawa panduan wawancara yang berisi pertanyaan sebagai panduan dalam penelitian ini.

c. Dokumentasi

"Dokumentasi adalah satu metode pengumpulan data yang digunakan dalam metodologi penelitian sosial. Pada intinya metode dokumentasi adalah metode yang digunakan untuk menelusuri data historis. Dengan demikian, pada penelitian sejarah, maka bahan dokumenter memegang peranan yang amat penting. Walau 
metode ini terbanyak digunakan pada penelitian ilmu sejarah, namun kemudian ilmu-ilmu sosial lain secara serius menggunakan dokumentasi sebagai pengumpulan data." (8)

"Dokumen merupakan rekaman kejadian masa lalu yang ditulis atau dicetak, dapat berupa catatan surat, buku harian dan dokumen-dokumen. Dokumen merupakan catatan peristiwa yang sudah berlalu. Dokumen bisa berbentuk tulisan, gambar, atau karya-karya monumental dari seseorang. Dokumen yang berbentuk tulisan misalnya catatan harian, sejarah kehidupan, biografi. Dokumen yang berbentuk gambar, misalnya foto, sketsa dan lain-lain. Dokumen yang berbentuk lisan misalnya rekaman gaya bicara. Dokumen yang berbentuk karya misalnya karya seni, yang dapat berupa gambar, patung, film, dan lain-lain." (14)

Dokumen yang akan dikumpulkan terdiri dari beberapa foto dan video Ritual Mandi Safar, yang akan peneliti paparkan di bawah ini:

a. Foto dan perekam suara ketika wawancara dengan warga, tokoh agama, tokoh adat (sekaligus berperan sebagai tokoh agama)

b. Foto dan video daun andungandung yang ditulis tujuh ayat-ayat Al-Qur'an yang terdiri dari empat surat Al-Qur'an, kemudian diikat ke bambu dan direndam ke parit

c. Foto dan video makan-makan, pembacaan do'a selamat dan do'a tolak bala'

d. Foto dan video masyarakat Melayu Dusun Sungai Jambu bersamasama mencuci piring, melipat terpal, dan membersihkan halaman masjid

e. Foto dan video pelaksanaan Ritual Mandi Safar di parit.

\section{Analisis Data}

Suatu analisis, apa pun bentuknya, melibatkan suatu cara berpikir. Analisis merujuk pada pengujian sistematis terhadap sesuatu untuk menentukan bagian-bagiannya, hubungan di antara bagian-bagian itu, serta hubungan bagian-bagian itu dengan keseluruhannya. Analisis etnografis merupakan penyelidikan berbagai bagian itu sebagaimana yang dikonseptualisasikan oleh informan. (52) Dalam penelitian ini menggunakan analisis domain, analisis taksonomi, dan analisis komponensial.

Dalam pendekatan etnografi, peneliti menggunakan analisis taksonomi dan analisis komponensial yang di dapat dari hasil observasi secara non partisipan. Setelah itu, peneliti mengajukan pertanyaan secara struktural, kemudian melakukan analisis taksonomi (indikator-indikator dari akidah) sebagaimana berikut ini:

a. Bagaimana Akidah dalam Praktik Ritual Mandi Safar pada Masyarakat Melayu Sungai Jambu di Kayong Utara?

Melakukan observasi non partisipan, kemudian mengamati dan membuat catatan bahwa tujuh ayat-ayat Al-Qur'an yang terdiri dari empat surat Al-Qur'an dituliskan ke daun andung-andung dan daun tersebut diikatkan ke bambu, setelah itu ditancapkan ke parit kemudian direndam di air. Selain itu, membaca Laa Ilaaha Illallaah dan ayat-ayat Al-Qur'an.

b. Bagaimana Ibadah dalam Praktik Ritual Mandi Safar pada Masyarakat Melayu Sungai Jambu di Kayong Utara?

Dalam penelitian ini, ibadah terletak pada bacaan zikir yaitu membaca Laa Ilaaha Illallaah, Wallahu Akbar, shalawat, menolong antarsesama manusia, sedekah, membaca do'a selamat, do'a memohon panjang umur, do'a tolak bala', dan membaca surat Al-Fatihah, an-Naas, alFalaq dan al-Ikhlas.

c. Bagaimana Akhlak dalam Praktik Ritual Mandi Safar pada Masyarakat Melayu Sungai Jambu di Kayong Utara?

Bahwa akhlak terhadap sesama manusia dalam penelitian ini yakni ketua adat, tokoh agama (sekaligus berperan sebagai ketua 
adat) menuliskan tujuh ayat-ayat Al-Qur'an yang terdiri dari empat surat Al-Qur'an ke daun andungandung. Selanjutnya, mereka membacakan do'a selamat, do'a memohon panjang umur, do'a tolak bala' dan masyarakat Melayu Sungai Jambu saling berbagi makanan kepada sesamanya. Selain itu, terdapat silaturrahim, mencuci piring dan merapikan tikar maupun terpal sebagai alas duduk secara bersama-sama, serta menjaga dan membersihkan kelestarian lingkungan.

Bagian yang terakhir mengajukan pertanyaan kontras, kemudian melakukan analisis komponensial (jawaban yang berbeda dari informan) dan membuat pedoman wawancara yang peneliti paparkan di bawah ini:

a. Bagaimana Akidah dalam Praktik Ritual Mandi Safar pada Masyarakat Melayu Sungai Jambu di Kayong Utara?

b. Bagaimana Ibadah dalam Praktik Ritual Mandi Safar pada Masyarakat Melayu Sungai Jambu di Kayong Utara?

c. Bagaimana Akhlak dalam Praktik Ritual Mandi Safar pada Masyarakat Melayu Sungai Jambu di Kayong Utara?

Kemudian pertanyaan di atas, peneliti melakukan wawancara mendalam tak terstruktur dengan tiga informan dan jawaban dari mereka memiliki persamaan dan perbedaan. Jawaban itu adalah sebagai berikut:

1. Abdul Mu'in

Mengenai prosesi Ritual Mandi Safar pada bulan safar ternyata bulan tersebut adalah bulan yang mendatangkan na'as, jika ritual tersebut tidak dilaksanakan maka akan mendatangkan na'as atau bala'. Oleh karena itu, pada tahap persiapannya menggunakan alat dan bahan-bahan tertentu antara lain daun andung-andung, pensil, air bersih serta ketupat lepas, lontong dan berbagai jenis makanan. Sebelum melaksanakan ritual tersebut, sebagian masyarakat terlebih dahulu berwudhu.

Kemudian, menuliskan tujuh ayat-ayat Al-Qur'an yang terdiri dari empat surat Al-Qur'an pada daun andung-andung yaitu surat Yasin (58), ash-Shaffat (79), ashShaffat (109), ash- Shaffat (120), ash- Shaffat (130), az-Zumar (73), dan al-Qadar (5). Masyarakat mengambil daun andung-andung yang ditanam di depan rumah maupun di wakaf pemakaman kemudian dihantarkan ke rumah tokoh agama (sekaligus berperan sebagai ketua adat) dan tokoh agama. Ritual Mandi Safar dilaksanakan sekitar pukul 07:30 atau dimulai pada pukul 08:00 tergantung jika sudah ramai berkumpul di halaman masjid.

Selanjutnya, air yang sudah dibawa diletakkan di atas tikar ataupun terpal, kemudian tokoh agama (sekaligus berperan sebagai ketua adat) dan tokoh agama serta warga juga ikut membaca Ilaahabratin Nabi Sayyidina Abu Bakar Umar Usman Ali Wa'ala Alihi Wasahbihi Sayyidina Rasulullah Kulhum Ajma'in Sayyi'un Lillah Humul, A'udzu billahi minasy syaithonir rojiim, setelah itu membacaBismillahirrahmanirrahi $m$, kemudian membaca surat AlFatihah sebanyak satu kali dan kemudian membaca surat alIkhlas tiga kali, surat al-Falak dan surat an-Naas satu kali. Kemudian membaca Laa Ilaaha Illallaah Wallahu Akbar sebanyak satu kali dan dilanjutkan dengan bacaan Bismillahirrahmanirrahim dan surat al-Falak, setelah itu dilanjutkan dengan bacaan yang sama Laa Ilaaha Illallaah Wallahu Akbar dan membaca Bismillahirrahmanirrahim, surat An-Naas. Kemudian, membaca Laa Ilaaha Illallaah Wallahu Akbar, dilanjutkan dengan 
membaca surat Al-Fatihah, do'a selamat, do'a memohon do'a memohon panjang umur, do'a tolak bala' dan shalawat.

Setelah itu, daun andungandung yang sudah ditulis menggunakan tujuh ayat dan empat surat Al-Qur'an dimasukkan ke air yang sudah dibacakan do'a selamat dan do'a tolak bala' guna sebagai penolak na'as atau bala'. Hal ini diperuntukan bagi masyarakat setempat ketika mandi di rumah. Bagi masyarakat Melayu Sungai Jambu yang ingin mandi di parit maka daun andung-andung yang sudah ditulis menggunakan tujuh ayat dan empat surat tersebut diikatkan ke bambu dan ditancapkan ke parit dengan tujuan terhindar dari na'as atau bala'.

Apabila rangkaian pembacaan do'a telah selesai maka ketupat lepas, lontong, dan berbagai jenis makanan yang dibawa oleh Masyarakat Melayu Dusun Sungai Jambu dimakan secara bersama-sama di halaman masjid dan dibagikan kepada sesamanya. Kemudian, pelaksanaan Ritual Mandi Safar dilakukan di parit tepatnya di depan masjid secara bersama orang tua dan anak-anak.

Ritual tersebut dilaksanakan pada hari rabu minggu terakhir bulan safar. Apabila Ritual Mandi Safar tidak dilaksanakan maka akan mendatangkan na'as atau bala'. (1)

2. Agok

Ritual Mandi Safar yang dilakukan masyarakat Melayu Sungai Jambu di Kayong Utara bahwa ritual tersebut dilaksanakan pada bulan safar, sehingga bulan safar dianggap bulan yang na'as. Jika ritual tersebut tidak dilaksanakan juga tidak mendatangkan na'as atau bala'. Mengenai persiapan Ritual Mandi Safar terlebih dahulu mengambil daun andung-andung, menyiapkan pensil, air, serta membawa makanan.

Setelah itu, daun andungandung yang sudah disiapkan dihantarkan ke rumah tokoh agama dan ketua adat (sekaligus berperan sebagai tokoh agama), kemudian menuliskan tiga suratsurat Al-Qur'an ke daun andungandung, tiga surat tersebut adalah QS.Yasin:58, QS. AshShaffat:109, dan yang terakhir ayat yang berbunyi Salamun 'ala ainul yakin. Namun disini, Datuk Agok tidak menuliskan surat-surat tersebut pada daun andungandung. Yang menulisnya adalah Datuk Jainul dan datuk Abdul Mu'in. Pelaksanaan Ritual Mandi Safar dimulai pada pukul 06:30 atau bisa pukul 07:00 di halaman masjid. Sebelum melaksanakan ritual tersebut, sebagian masyarakat terlebih dahulu berwudhu.

Selanjutnya, air yang sudah dibawa diletakkan di atas tikar, kemudian tokoh agama (sekaligus berperan sebagai ketua adat) dan tokoh agama membaca surat $\mathrm{Al}$ Fatihah sebanyak satu kali dan kemudian membaca surat alIkhlas, surat al-Falak dan surat an-Naas satu kali. Setelah membaca surat al-Ikhlas kemudian membaca Laa Ilaaha Illallaah, Wallahu Akbar sebanyak satu kali dan dilanjutkan dengan bacaan surat al-Falak, setelah itu dilanjutkan dengan bacaan yang sama Laa Ilaaha Illallaah, Wallahu Akbar dan membaca surat An-Naas. Kemudian, membaca do'a selamat, do'a memohon panjang umur, do'a tolak bala' dan shalawat.

Setelah itu, daun andungandung yang sudah ditulis menggunakan tiga ayat dan tiga surat Al-Qur'an dimasukkan ke air yang sudah dibacakan do'a selamat dan do'a tolak bala' guna sebagai penolak na'as atau bala'. Hal ini diperuntukan bagi 
masyarakat setempat ketika mandi di rumah. Bagi masyarakat Melayu Sungai Jambu yang ingin mandi di parit maka daun andungandung yang sudah ditulis menggunakan tujuh ayat dan empat surat tersebut diikatkan ke bambu dan ditancapkan ke parit dengan tujuan terhindar dari na'as atau bala'.

Apabila rangkaian pembacaan do'a telah selesai maka ketupat, lontong, dan berbagai jenis makanan yang dibawa oleh Masyarakat Melayu Sungai Jambu dimakan secara bersamasama di halaman masjid dan dibagikan kepada sesamanya. Kemudian, pelaksanaan Ritual Mandi Safar dilakukan di parit tepatnya di depan masjid secara bersama orang tua dan anak-anak. Tradisi tersebut dilaksanakan pada hari rabu minggu terakhir bulan safar. (4)

3. Jainul

Ritual Mandi Safar dilakukan pada hari rabu minggu terakhir pada bulan safar dan hanya meneruskan tradisi orang-orang zaman dahulu. Jika tradisi tersebut tidak dilaksanakan juga tidak mendatangkan na'as atau bala'. Ritual Mandi Safar dilaksanakan pada hari rabu minggu terakhir bulan safar, karena orang-orang zaman dahulu menganggap hari tersebut na'as.

Untuk persiapan Ritual Mandi Safar pertama-tama mengambil daun andung-andung, menyiapkan pensil, air, serta membawa makanan. Setelah itu, daun andung-andung yang sudah disiapkan kemudian dihantarkan ke rumah tokoh agama, ketua adat (sekaligus berperan sebagai ketua adat), kemudian menuliskan tiga surat-surat Al-Qur'an ke daun tersebut, tiga surat itu adalah QS.Yasin:58, QS. AshShaffat:109, dan yang terakhir ayat yang berbunyi Salamun 'ala ainul yakin.
Pelaksanaan Tradisi Mandi Safar dimulai kadang pukul jam 06:30 atau paling lama pukul 08:00. Sebelum melaksanakan ritual tersebut, sebagian masyarakat terlebih dahulu berwudhu. Pada tahap pelaksanaannya, air yang sudah dibawa diletakkan di atas tikar, kemudian tokoh agama (sekaligus berperan sebagai ketua adat) dan tokoh agama membaca surat AlFatihah sebanyak satu kali dan kemudian membaca surat alIkhlas, surat al-Falak dan surat an-Naas satu kali. Setelah membaca surat al-Ikhlas kemudian membaca Laa Ilaaha Illallaah, Wallahu Akbar sebanyak satu kali dan dilanjutkan dengan bacaan surat al-Falak, setelah itu dilanjutkan dengan bacaan yang sama Laa Ilaaha Illallaah, Wallahu Akbar dan membaca surat An-Naas. Kemudian, membaca do'a selamat do'a memohon panjang umur, do'a tolak bala' dan shalawat.

Setelah itu, daun andungandung yang sudah ditulis menggunakan tiga ayat dan tiga surat Al-Qur'an dimasukkan ke air yang sudah dibacakan do'a selamat dan do'a tolak bala'. Hal ini diperuntukan bagi masyarakat setempat ketika mandi di rumah. Bagi masyarakat Melayu Sungai Jambu yang ingin mandi di parit maka daun andung-andung yang sudah ditulis menggunakan tujuh ayat dan empat surat tersebut diikatkan ke bambu dan ditancapkan ke parit.

Apabila rangkaian pembacaan do'a telah selesai maka ketupat, lontong, dan berbagai jenis makanan yang dibawa oleh Masyarakat Melayu Dusun Sungai Jambu dimakan secara bersama-sama di halaman masjid dan dibagikan kepada sesamanya. Kemudian, pelaksanaan Tradisi Mandi Safar dilakukan di parit tepatnya di depan masjid secara 
bersama orang tua dan anak-anak. (16)

Dari jawaban tiga informan di atas, terdapat perbedaan yang yaitu menulis surat-surat AlQur'an ke daun andung-andung. Berikut perbedaan itu peneliti peroleh dari datuk Abdul Mu'in bahwa surat-surat Al-Qur'an dituliskan ke daun andung-andung sebanyak tujuh ayat yang terdiri dari empat surat-surat Al-Qur'an, sedangkan datuk Agok dan datuk Jainul hanya tiga ayat dan tiga surat Al-Qur'an. Selain itu, datuk Abdul Muin terdapat perbedaan membaca Ilaahabratin Nabi Sayyidina Abu Bakar Umar Usman Ali Wa'ala Alihi Wasahbihi Sayyidina Rasulullah Kulhum Ajma'in Sayyi'un Lillah Humul.

Selain itu, terdapat juga dua jawaban yang sama dari datuk Abdul Mu'in dan datuk Agok, bahwa bulan safar bulan yang na'as atau bala'dan surat-surat AlQur'an yang dituliskan ke daun andung-andung kemudian direndamkan ke air sebagai penolak na'as atau bala', sedangkan datuk Jainul menerangkan bahwa orang-orang zaman dahulu menganggap bulan safar bulan na'as atau bala'. Mengenai pelaksanaan Ritual Mandi Safar, datuk Abdul Mu'in menerangkan jika tidak dilaksanakan tradisi tersebut akan mendatangkan na'as atau bala', sedangkan menurut datuk Agok dan datuk Jainul tidak ada na'as atau bala'.

\section{Teknik Pemeriksaan Keabsahan} Data

Untuk pengecekan keabsahan data, maka peneliti menggunakan member check dan Triangulasi.

\section{a. Member Check}

Pada penelitian ini menggunakan member check yaitu informasi yang diperoleh dari tokoh agama dan ketua adat (sekaligus berperan sebagai tokoh agama) di cek kembali dengan melakukan pengulangan wawancara tentang garis besar penelitian yang diajukan sebelumnya, supaya dapat memperbaiki kekeliruan atau dapat merubah sesuatu yang dianggap kurang tepat dan tidak sempurna. Tujuannya adalah menyesuaikan data yang telah diperoleh dengan mengambil data yang diperoleh dari pengulangan wawancara terakhir. Hal tersebut dilakukan agar data yang di dapat lebih akurat. Peneliti merangkum hasil pembicaraan dan meminta informan untuk mengadakan perbaikan bila perlu dan menginformasikan kesesuaiannya dengan informasi yang diberikannya.

Untuk itu peneliti perlu menguji kebenaran hasil wawancara dengan cara melakukan member check yaitu untuk mengetahui sejauh mana data yang diperoleh peneliti dalam pengumpulan data dan membuat simpulan tentang "Agama dan Modernitas dalam Praktik Ritual Mandi Safar di Kayong Utara".

b. Triangulasi

"Teknik

pemeriksaan keabsahan data yang memanfaatkan sesuatu yang lain di luar data itu untuk keperluan pengecekan atau sebagai pembanding data itu." (24) Triangulasi adalah "sebagai teknik pengumpulan data yang bersifat menggabungkan dari berbagai teknik pengumpulan data dan sumber data yang telah ada.

Bila peneliti melakukan pengumpulan data dengan triangulasi, maka sebenarnya penel

iti mengumpulkan data yang sekaligus menguji kredibilitas data, yaitu mengecek kredibilitas data dengan berbagai teknik pengumpulan data dan berbagai sumber data." (54) Tiga jenis triangulasi yaitu: triangulasi data, 
peneliti, dan triangulasi teori (metode, teknik). (44)

Pada penelitian ini, peneliti menggunakan triangulasi data. Dalam triangulasi data, data pertama tidak harus dianggap sebagai sudah bersifat valid, tetapi justru harus diragukan kebenarannya, sehingga perlu diuji melalui data lain dengan sumber yang berbeda, demikian seterusnya sehingga data yang diperoleh benar-benar dapat dianggap objektif. (44)

Oleh karena itu, peneliti melakukan pengecekan wawancara kembali terhadap data yang berbeda supaya data yang diperoleh peneliti benar-benar valid mengenai "Agama dan Modernitas dalam Praktik Ritual Mandi Safar di Kayong Utara”.

\section{Hasil dan Diskusi}

Ritual Mandi Safar dari dulu hingga sekarang terjadi perubahan, yang mana ritual tersebut tidak ada kebersamaan dalam arti berkumpul di halaman masjid dan tidak ada membawa makanan, minuman, dan ketika mandi tidak secara bersama-sama di parit tepatnya di depan masjid. Jika dibandingkan dengan sekarang ini, Masyarakat Melayu Sungai Jambu telah melakukan musyawarah bahwa Ritual Mandi Safar dilaksanakan di halaman masjid, mandi bersama-sama di parit dan seikhlasnya membawa makanan dan minuman. Sebelum melaksanakan ritual tersebut, sebagian masyarakat terlebih dahulu berwudhu, membaca ayatayat Al-Qur'an, zikir, mengucapkan kalimat Laa Ilaaha Illallaah, do'a-do'a, shalawat, dan tolong-menolong tidak ada perubahan dari dulu hingga sekarang.

Mengenai Ritual Mandi Safar pada bulan safar ternyata bulan tersebut adalah bulan yang mendatangkan na'as, jika tidak dilaksanakan maka akan mendatangkan na'as atau bala'. Oleh karena itu, Masyarakat Melayu Sungai Jambu menyiapkan alat dan bahan-bahan tertentu antara lain daun andung-andung, pensil, air bersih serta ketupat lepas, lontong dan berbagai jenis makanan.
Bagi masyarakat Melayu Sungai Jambu yang ingin mandi di parit maka daun andung-andung yang sudah ditulis tujuh ayat dan empat surat Al-Qur'an diikatkan ke bambu dan ditancapkan ke parit untuk mandi secara bersama-sama dengan tujuan terhindar dari na'as atau bala'.

Selain itu, ternyata Masyarakat Melayu Sungai Jambu mempercayai ayatayat Al-Qur'an yang dituliskan ke daun andung-andung sebagai penolak na'as atau bala' dalam arti mereka mempercayai ayatayat Al-Qur'an bukan mempercayai daun andung-andung sebagai pencegah dari bencana. Melaksanakan Ritual Mandi Safar sebagai ungkapan rasa syukur dan tawakkal dan memohon perlindungan kepada Allah Subhanahu wa ta'ala. Selain itu, Masyarakat tersebut mempercayai bahwa "Tidak Ada Tuhan Selain Allah" serta yang menciptakan manusia adalah Allah Subhanahu wa ta'ala.

Berdasarkan hal tersebut di atas, setelah peneliti analisis bahwa telah ditemukan akidah, ibadah, dan akhlak pada Ritual Mandi Safar, yakni peneliti paparkan sebagai berikut:

Sebelum melaksanakan ritual tersebut, sebagian masyarakat terlebih dahulu berwudhu, menuliskan tujuh ayat-ayat AlQur'an yang terdiri dari empat surat AlQur'an pada daun andung-andung yaitu surat Yasin (58), ash-Shaffat (79), ashShaffat (109), ash- Shaffat (120), ashShaffat (130), az-Zumar (73), dan al-Qadar (5). Membaca Ilaahabratin Nabi Sayyidina Abu Bakar Umar Usman Ali Wa'ala Alihi Wasahbihi Sayyidina Rasulullah Kulhum Ajma'in Sayyi'un Lillah Humul, A'udzu billahi minasy syaithonir rojiim, setelah itu membaca Bismillahirrahmanirrahim, surat Al-Fatihah, surat al-Ikhlas, surat al-Falak dan surat an-Naas, Laa Ilaaha Illallaah Wallahu Akbar, do'a selamat, do'a memohon dipanjangkan umur, do'a tolak bala' dan shalawat, serta makanan yang dibawa dibagikan kepada sesama. Selain itu, terdapat silaturrahim, tolong menolong dan menjaga kelestarian lingkung an.

\section{Kesimpulan}

Dari semua penjelasan yang sudah dibahas di atas, maka ditarik kesimpulan 
bahwa kepercayaan Masyarakat Melayu Sungai Jambu mengenai bulan safar bulan yang mendatangkan na'as dan bala' berawal dari musibah yang menimpa Nabi Muhammad Shallallahu 'Alaihi Wa Sallam berdakwah dan ingin dibunuh oleh orangorang kafir, sehingga masyarakat setempat percaya bahwa bulan safar mengandung banyak na'as dan bala', sehingga melaksanakan Ritual Mandi Safar.

Oleh karena itu, Ritual Mandi Safar sebagian dalam ritual tersebut terdapat unsur akidah, yakni berniat melaksanakan ritual tersebut karena Allah Subhanahu wa ta'ala. Sebelum melaksanakan ritual tersebut, sebagian masyarakat terlebih dahulu berwudhu, membaca ayat-ayat AlQur'an dan mengucapkan Laa Ilaaha Illallaah. Untuk unsur ibadah terletak pada bacaan Laa Ilaaha Illallaah Wallahu Akbar, shalawat, do'a selamat, do'a memohon panjang umur, dan do'a bala. Selanjutnya, unsur akhlak terletak pada ungkapan rasa syukur dan tawakkal kepada Allah Subhanahu wa ta'ala dengan bersedekah makanan sehingga pada bulan safar terhindar dari na'as atau bala', menolong antara sesama manusia, menjaga kelestarian lingkungan dan silaturrahim.

\section{Daftar Pustaka}

1. Abdul Mu'in. Wawancara. 2018.

2. Abu Muhammad Iqbal. Konsep

Pemikiran Al-Ghazali Tentang

Pendidikan. Madiun: Madiun Jaya Star Nini, 2013.

3. Abudin Nata. Akhlak Tasawuf. Jakarta: PT GrafindoPersada, 2011.

4. Agok. Wawancara. 2018.

5. Ahmad Mustofa. Akhlak Tasawuf. Bandung: CV Pustaka Setia, 2010.

6. Al-Ghazali. Rahasia Zikir dan Do'a. Bandung: Karisma, 1997.

7. Asmaran. Pengatar Studi Akhlak. Jakarta: PT GrafindoPersada, 2002.
8. Burhan Bungin. Penelitian Kualitatif. Jakarta: Kencana Prenada Media Group, 2009.

9. Bustanuddin Agus. Agama dalam Kehidupan Manusia. Jakarta: PT.RajaGrafindo Persada, 2007.

10. Dadang Kahmad. Metode Penelitian Agama. Bandung: CV Pustaka Setia, 2000.

11. Daulay MR. Jurnal Thariqah Ilmiah Vol. 01, No. 01 Januari. 01: 15, 2014.

12. Daulay MR. Studi Pendekatan AlQuran. Thariqah Ilm 1, 2014.

13. Deddy Mulyana. Metodologi Penelitian Kualitatif Paradigma Baru Ilmu Komunikasi dan Ilmu Sosial Lainnya. Bandung: PT Remaja Rosdakarya, 2002.

14. Djam'an Satori, Aan Komariah. Metodologi Penelitian Kualitatif. Bandung: Alfabeta, 2011.

15. Habibah S. Akhlak Dan Etika Dalam Islam. J Pesona Dasar 1, 2015.

16. Jainul. Wawancara. 2018.

17. Jamil R. Peranan Pembelajaran Modeling Dalam Meningkatkan Keterampilan Beribadah Siswa Di Madrasah Aliyah Negeri (MAN)-3 Medan. ANSIRU PAI Pengemb Profesi Guru Pendidik Agama Islam 1: 105141, 2017.

18. Jamil R. Peranan Pembelajaran Modeling Dalam Meningkatkan Keterampilan Beribadah Siswa Di Madrasah Aliyah Negeri (MAN)-3 Medan. ANSIRU PAI : Pengembangan Profesi Guru Pendidikan Agama Islam.1:105-141, 2017.

19. Juliansyah Noor. Metodologi Penelitian: Skripsi, Tesis, Disertasi, dan Karya Ilmiah. Jakarta: Kencana Prenada Media Group, 2016. 
20. Kaelany. Islam Iman dan Amal Saleh. Jakarta: PT Rineka Cipta, 2000.

21. Katni. Pendidikan Keimanan Di Madrasah (Studi Strategi Pembinaan Akidah Islamiyah Di Ma Pondok Pesantren Darul Fikri Ponorogo). Muaddib Studi Kependidikan Dan Keislam 3: 1-17, 2016.

22. Koentjaraningrat. Pengantar Antropologi Pokok-Pokok Etnografi II. Jakarta: PT Rineka Cipta, 1998.

23. L B, Mursalin A, Masburiah M. Ritual Mandi Safar: Akulturasi Islam dan Tradisi Lokal: Studi Kasus di Desa Air Hitam Laut Kecamatan Sadu Kabupaten Tanjung Jabung Timur. Kontekst- J Penelit Sos Keagamaan 23: 37137, 2008.

24. Lexy J Moleong. Metodologi Penelitian Kualitatif. Bandung: Remaja Rosdakarya, 2002.

25. Mahmud. Metode Penelitian Pendidikan. Bandung: CV Pustaka Setia, 2011.

26. Mawardi K. Shalawatan: Pembelajaran Akhlak Kalangan Tradisionalis. INSANIA J Pemikir Altern Kependidikan 14: 500-511, 1970.

27. Mawardi K. Shalawatan: Pembelajaran Akhlak Kalangan Tradisionalis. INSANIA J Pemikir Altern Kependidikan 14: 500-511, 2009.

28. Mawardi Labay El-Suthani. Zikir dan Do'a Mencapai Nikmatnya Ibadah Puasa. Jakarta: Al Mawardi Prima, 2004.

29. Mohammad Daud Ali. Pendidikan Agama Islam. Jakarta: PT RajaGrapindo Persada, 2004.

30. Mubarak SFD. Kepercayaan Masyarakat Banjar Terhadap Bulan Safar: Sebuah Tinjauan Psikologis. Al-
Banjari J Ilm Ilmu-Ilmu Keislam 11, 2015.

31. Muhammad Ahmad. Tauhid Ilmu Kalam. Bandung: CV Pustaka Setia, 2009.

32. Muhammad Al-Gazzali. Aqidah Muslim. Jakarta: CV Pedoman Ilmu Jaya, 1986.

33. Muhammad Arifin Ilham. RenunganRenungan Zikir. Depok: Intuisi Press, 2004.

34. Muhammad Chirzin. Konsep dan Hikmah Akidah Islam. Yogyakarta: Mitra Pustaka, 1997.

35. Muhammad Idrus. Metode Penelitian Ilmu-Ilmu Sosial. Yogyakarta: UII Press Yogyakarta, 2007.

36. Muhammad Solihin, Rosyid Anwar. Akhlak Tasawuf Manusia, Etika, dan Makna Hidup. Bandung: Nuansa, 2005.

37. Muhtifah L. Pola Pengembangan Kurikulum Pesantren Kasus AlMukhlishin Mempawah Kalimantan Barat. J Pendidik Islam 27: 203-222, 2012.

38. Nasharuddin. Akhlak (Ciri Manusia Paripurna). Jakarta: PT Raja Grapindo Persada, 2015.

39. Nashir bin Abdullah Al Qafari. Kesatuan Aqidah Empat Imam Madzhab. Jakarta: Mustaqimm, 2001.

40. Nurhayati D. Islam And Local Interests In The Safar Bath Tradition Of Malay People In Sungai Jambu Sub Vilage, Kayong Utara. Khatulistiwa 8: 14-28, 2018.

41. Nurhayati D. Islam And Local Interests In The Safar Bath Tradition Of Malay People In Sungai Jambu Sub Vilage, Kayong Utara. Khatulistiwa 8: 14, 2019.

42. Nurozi A. Rebo Wekasan Dalam Ranah Sosial Keagamaan Dikabupaten 
Tegal Jawa Tengah (Analisis Terhadap

Ritual Rebo Wekasan Di Desa

Sitanjung Lebaksiu). -Nuha J Kaji

Islam Pendidik Budaya Sos 3: 125-136, 2016.

43. Nurozi A. Rebo Wekasan Dalam Ranah Sosial Keagamaan Di

Kabupaten Tegal Jawa Tengah. AnNuha: Jurnal Kajian Islam,

Pendidikan, Budaya \& Sosial $3: 125-$ 136,2016.

44. Nyoman Kutha Ratna. Metodologi Penelitian Kajian Budaya dan IlmuIlmu Sosial Humaniora Pada Umumnya. Yogyakarta: Pustaka Pelajar, 2010.

45. Rohimin dkk. Harmonisasi Agama dan Budaya Indonesia 2. Jakarta: Balai Penelitian dan Pengembangan Agama Jakarta, 2009.

46. Rosady Ruslan. Metode Penelitian Public Relations dan Komunikasi. Jakarta: Rajawali Pres, 2008.

47. Rosihon Anwar. Akidah Akhlak. Bandung. Bandung: CV Pustaka Setia, 2008.

48. Rosyidi AW. Doa daLam Tradisi Islam Jawa. El-Harakah 14:88-100,2012.

49. Rusmin Tumanggor, Kholis R. Nurochim. Ilmu Sosial dan Budaya Dasar. Jakarta: Kencana Prenada Media Group, 2012.

50. Saad Riyadh. Jiwa Dalam Bimbingan Rasulullah. Jakarta: GemaInsani, 2007.

51. Soepardjo. Integrasi Budi Pekerti Dalam Pendidikan Agama Islam. Solo: PT Tiga Serangkai Pustaka Mandiri, 2003.

52. Spradley James P. Metode Etnografi. Yogyakarta: Tiara Wacana, 2007.

53. Sudarsono S. Pendidikan Ibadah Perspektif Al-Quran Dan Hadits. CENDEKIA J Studi Keislam 4:55-65, 2018.
54. Sugiyono. Metode Penelitian Kuantitatif, Kualitatatif, dan $R \& D$. Bandung: Alfabeta, 2016.

55. Supartono. Ilmu Budaya Dasar. Jakarta: Ghalia Indonesi, 2004.

56. Syaikh Ja'far Subhani. Studi Kritis Faham Wahabi Tauhid dan Syirik. Bandung: Mizan, 1996.

57. Syeikh 'izzuddin Ibnu Abdis Salam. Kaidah-Kaidah Hukum Islam. Bandung: Nusa Media, 2011.

58. Syukriadi Sambas, Tata Sukayat. Quantum Do 'a Agar Do'a Tak Terhijab dan Mudah Dikabulkan oleh Allah. Jakarta: PT Mizan Publika, 2004.

59. Tim Dosen Pendidikan Agama Islam Universitas Lampung. Pendidikan Agama Islam Berbasis Karakter di Perguruan Tinggi Disertasi Buku Panduan Pratikum Pengamalan Ibadah. Jakarta: Rajawali Pres, 2014.

60. Toto Suryana dkk. Pendidikan Agama Islam. Bandung: Tiga Mutiara, 1997.

61. Yadi Purwanto. Epistemologi Psikologi Islam Dialektika Pendahuluan Psikologi Barat dan Psikologi Islam. Bandung: PT Refika Aditama, 2007.

62. Yusriadi Y. Berandep, Kearifan Lokal Masyarakat Melayu Di Dabong, Kubu Raya, Kalimantan Barat. Khatulistiwa 7,2017.

63. Zaenuddin. Pengantar Antropologi. Pontianak: STAIN Pontianak Press, 2013.

64. Zahruddin, Hasanuddin Sinaga. Pengantar Studi Akhlak. Jakarta: PT GrafindoPersada, 2004.

65. Zainuddin Ali. Pendidikan Agama Islam. Jakarta: Bumi Aksara, 2007. 
Jurnal Studi Agama dan Masyarakat 165

Vol. 15, No. 2, Desember 2019, p. 140-165

66. Zainuddin, Muhammad Jamhari. $A l$ -

Islam 1 Aqidah dan Ibadah. Bandung:

CV Pustaka Setia, 1999. 